
Not for reproduction, distribution or commercial use.

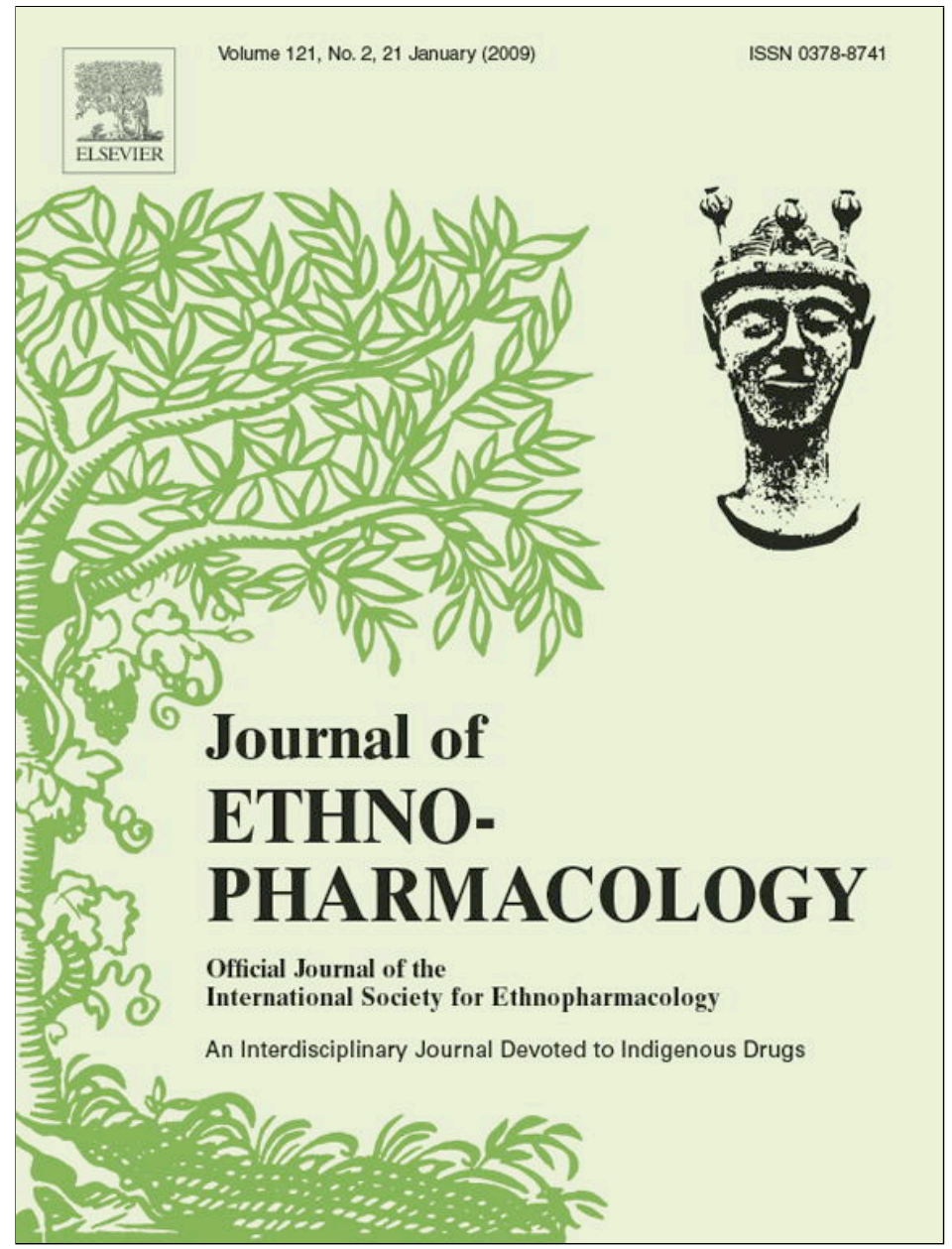

This article appeared in a journal published by Elsevier. The attached copy is furnished to the author for internal non-commercial research and education use, including for instruction at the authors institution and sharing with colleagues.

Other uses, including reproduction and distribution, or selling or licensing copies, or posting to personal, institutional or third party websites are prohibited.

In most cases authors are permitted to post their version of the article (e.g. in Word or Tex form) to their personal website or institutional repository. Authors requiring further information regarding Elsevier's archiving and manuscript policies are encouraged to visit:

http://www.elsevier.com/copyright 


\title{
A comparison of medicinal plant use in Sardinia and Sicily-De Materia Medica revisited?
}

\author{
Marco Leonti*, Laura Casu, Francesca Sanna, Leonardo Bonsignore \\ Dipartimento Farmaco Chimico Tecnologico, Università di Cagliari, Facoltà di Farmacia, Via Ospedale 72, 09124 Cagliari (CA), Italy
}

\section{A R T I C L E I N F O}

\section{Article history:}

Received 1 October 2008

Received in revised form 23 October 2008

Accepted 24 October 2008

Available online 6 November 2008

\section{Keywords:}

Ethnobotany

Dioscorides

Comparative analysis

Mediterranean

History of medicinal plant use

\begin{abstract}
A B S T R A C T
Aim of the Study: Written records of oral medical traditions have had significant impact on the development of medicine and the pharmacopoeias. Modern ethnobotanical studies in Europe and the Mediterranean region, however, have so far largely overlooked the richness and accuracy of historic sources and ignored their probable influence on the development of today's local traditional medicines. Here, we explore the common fundament of traditional knowledge for the medicinal plant uses in Sardinia and Sicily by comparing the selection of medicinal species and specific uses with those of Dioscorides' De Materia Medica.

Materials and methods: We use (i) a quantification of citations for medicinal species mentioned in ethnobotanical studies conducted in Sardinia and Sicily (ii) a comparison of the flora and medicinal flora with a $\chi^{2}$-test (iii) a binomial approach recently introduced into ethnobotany (iv) a comparison of the most frequently used species with the indications cited in Dioscorides' De Materia Medica (v) and a crosscheck of all mentioned species with their appearance in Berendes' translation of De Materia Medica.

Results: We identified a core group of 170 medicinal species used on either islands, which accumulate $74 \%$ of all citations and are best represented in De Materia Medica. The 15 most frequently used species of both islands demonstrate intriguing parallels for indications with Dioscorides' work.

Conclusion: The ethnopharmacopoeia of Sicily and Sardinia are shallow stereotypes of the different editions of De Materia Medica and talking of oral tradition in this respect is a contradiction. The medicinal species of Sardinia and Sicily are largely widespread and common species, including many weeds, which are not facing threat of extinction. Therefore, using traditional medicinal practices as an argument for conservation biology or vice versa is not scientifically sound.
\end{abstract}

(c) 2008 Elsevier Ireland Ltd. All rights reserved.

\section{Introduction}

The earliest evidence of a classical Mediterranean drug and food plant in relation with human culture comes from the area of the Linear Pottery Culture (Linienbandkeramik Kultur), outside from its natural habitat, and stems from Papaver somniferum ssp. setigerum L. Mostly charred seeds of wild but cultivated (Bakels, 1982; Knoerzer, 1971) opium poppy were found in cultural sediments dated $5000 \mathrm{BC}$ in the area between Pleszow (Poland) (Wasylikowa, 1989), Roessing (Germany) (Willerding, 1988) and Michelsberg (France) (Bakels, 1984) with an accumulation of finds in the northern Rhineland between Cologne and Aachen (Knoerzer, cited in Willerding, 1980). The earliest subfossil remains of Hyoscyamus niger L. seeds were found in a filled up Linear Pottery pond in Kueckhoven (Germany) and dated 5090 BC (Dendrochron.)

\footnotetext{
* Corresponding author. Tel.: +39 070 6758712; fax: +39 0706758553.

E-mail addresses: mleonti@unica.it, marcoleonti@netscape.net (M. Leonti).
}

(Knoerzer, 1992), while the earliest find of Atropa belladonna L. seeds comes from an early Neolithic tomb at Manerba (Italy) dated to around $4000 \mathrm{BC}$ (Barfield et al., 1992). It is, however, not possible to deduct a medicinal use from such archeobotanical rests. The first secure evidence for a medicinal or ceremonial utilization of a drug plant in the Mediterranean holds a goddess figurine from the late Minoic Gazi in Crete (1400-1200 BC), made from clay, and decorating the cover of this journal. However, since at least 4000 years we do have written records of oral medical traditions, which had a significant impact on the development of medicine (Mann, 1984, cited in Johns, 1990, p. 264). In fact, many plants from ancient herbals are included in modern pharmacopoeias (Mann, 1984, cited in Johns, 1990, p. 264).

We have previously analysed the use of wild gathered food plants in different parts of Mediterranean Europe (Leonti et al., 2006). Inspired by Logan and Dixon (1994) and Johns (1990) we hypothesized that the modern pharmacopoeias co-evolved with the spread of weeds during the Neolithic period when the increasing use of these weeds as a food source, promoted the knowledge 
about the pharmacological properties of such species. In another study we analyzed the antiquity of medicinal plant usage by comparing the medicinal plant usage of two Macro-Mayan ethnic groups (Leonti et al., 2003a).

In this work we compare the use and selection of medicinal plants by the inhabitants of Sicily and Sardinia, two Mediterranean islands of Italy. More precisely, we explore the fundament of common traditional knowledge for the medicinal plant use by the inhabitants of these two islands.

We implement different methods and methodologies: (i) a quantification of citations for medicinal species mentioned in ethnobotanical studies conducted on either islands, (ii) a binomial analysis recently introduced into ethnobotany by Bennett and Husby (2008), (iii) a comparison of the floras and a cross-cultural analysis of the medicinal floras with a $\chi^{2}$-test (iv) a comparison of the 15 most frequently used species of either islands with the indications cited by Dioscorides' De Materia Medica and (v) a crosscheck of all mentioned species with their appearance in Berendes' translation of De Materia Medica.

A study of the drug and plant content of works by Cervantes like that of Don Quixote (Lopez-Muñioz et al., 2006; Pardo-deSantayana et al., 2006) and the reconstruction of ancient materia medica of whole regions or communities through the analysis of written sources and documents (Lev, 2002; Lev and Amar, 2006) has been approached before. As well, a crosscheck of a collection of botanical materia medica from a monastery with the species of Dioscorides' De Materia Medica has been undertaken (Lardos, 2006). Ethnobotanical studies in the Mediterranean are mushrooming but do, however, largely overlook the heritage of traditional medicine and ignore the influence of historic written sources like Dioscorides' De Materia Medica and the interpretations thereof on the development of today's local traditional medicines. The influence of the classical works is generally acknowledged but if reference is made, then it is done not exceeding a lump sum mentioning of these operas.

We chose Sardinia and Sicily for this comparison because they are adequate geographic areas for our approach because (i) the territory of both islands is covered fairly well with ethnobotanical studies, (ii) the flora and ethnoflora of islands can be assessed readily, (iii) both islands received similar cultural influences but to a different extent, (iv) they share many ecological habitats and plant species.

\subsection{The Mediterranean flora}

The Mediterranean region is considered to be a major centre of plant diversity and is estimated to harbour about $24.000-25.000$ species (Heywood, 1999). The region termed “Mediterranean" comprises different ecological conditions, a range of different climates, and has experienced different cultural impacts (Heywood, 1999). It is these parameters together with the palaeo-geographic history, bringing together the continents of Africa and Eurasia, which are responsible for the observed species richness (Giardina et al., 2007).

The actual Mediterranean flora, in particular the flora of southern Italy is a lowland flora characterized by the coastal environment. Only through the petering out river valleys the flora of the costal fringe protrudes farther inland (Eberle, 1975, p. 20). With increasing distance from the sea and rising altitude the climate changes resulting in milder summer drought, colder winters, and more temperate summers. This graduation of the climate finds its reflection in the formation of distinct vegetation zones. The Mediterranean flora resides in coastal proximity and in the adjacent hillsides and lower montane zones usually not higher than 400-500 $\mathrm{m}$ a.s.l. The distribution of the typical Mediterranean vegetation falls together with the cultivation of the oil tree (Olea europaea L.) and the vegetative association of the Macchia. The margin of the distribution of the oil tree is followed by a belt of deciduous trees, like summer green oaks (Quercus spp.) and chestnut (Castanea sativa L.).

\subsection{History of medicinal plant use in the Mediterranean-De Materia Medica}

According to Riddle (1985, p.xvii), the knowledge of medicine of the modern era from Viking north to the Indian Ocean came more from the efforts of one man, Pedanius Dioscorides (ca. AD 40-80), than from any other person. His five-volume book, De Materia Medica, was the standard guide to drugs until the 17 th century and has seen numerous re-editions of the Greek text and the Latin and Arabic translations. There were as well printings produced in modern languages like Italian, French, German, Czech, Spanish, Dutch and English (Riddle, 1985, p. xix). De Materia Medica is an assemblage of information about the properties of around 1000 natural product drugs derived mostly from the plant kingdom but including as well drugs from animal and mineral sources (Riddle, 1985, p. xviii). Dioscorides included remedies from southern Arabia like myrrh (Commiphora spp.) and frankincense (Boswellia spp.) and exoticas from the East such as cloves (Sizygium aromaticum (L.) Merr. and L.M. Perry) and cinnamon (Cinnamomum spp.) and makes references to plant habitats ranging from India, Turkey, Egypt, Somalia and Syria, to Greece, Italy, Sardinia, Africa, Spain and other regions (Riddle, 1985, p. 3). One technical problem with a straightforward interpretation of Dioscorides' work is, however, plant identification. Modern scientific names for individual plants do not correspond exactly with Dioscorides' "kinds" of plants and animals (Riddle, 1985, p. xxv). In 1902 the German pharmacist Julius Berendes translated De Materia Medica into German and achieved to identify drugs from around 670 plant species. In the introduction he explains: "Dioscorides was able to describe some plants with such a precision that they can be distinguished without trouble. For the larger part we have to make use of the medical application, the habitat, the distribution, the tradition, as well as the actual names" (Berendes, 1902, p. 4). Berendes' plant identifications are based on authors like Carl Fraas, John Sibthorp, Heinrich Friedrich Link and Curtius Sprengel, all of them specialists of the Greek and ancient flora. However, one should be concerned that there are possibilities for errors (Riddle, 1985, p. xxv). Berendes (1902, p. vi) used Curtius Sprengel's text for his translation, which was printed in Greek in 1829-1830 and, which on his part, was based on Janus Saracenus' commentary from 1598 (Riddle, 1985, p. xxv). The scanned opera of Berendes (1902) can be skimmed through online at: http://www.heilpflanzen-welt.de/buecher/DioskuridesArzneimittellehre/.

With respect to Italy it was Andrea Matthioli's opera "I Discorsi" edited for the first time in 1544 that divulged Dioscorides' cognition. However, Matthioli a botanist and physician did not content himself with a mere translation. Matthioli not only commented Dioscorides' chapters introducing different uses and observations but also introduced new species from the New World like tomato (Lycopersicum esculentum Mill.), prickly pear (Opuntia ficus-indica L.) as well as Citrus spp. and others. Andrea Matthioli tolerated neither rivals nor corrections and those daring to disagree with him were abused (Osbaldeston, 2000). The other authority on Dioscorides was Andrés Laguna, a physician and philosopher from Segovia, Spain. His Castilian translation from 1555 was reprinted more than 20 times with the last edition being that of Madrid in 1752 (Amat di San Filippo, 1990, p. 206). Both, Laguna's and Matthioli's translations came with woodcut illustrations (Matthioli, 1568; Laguna, 1555) imposing the plant identification of the 2 authors and giving less margin for different interpretations. Probably it were 


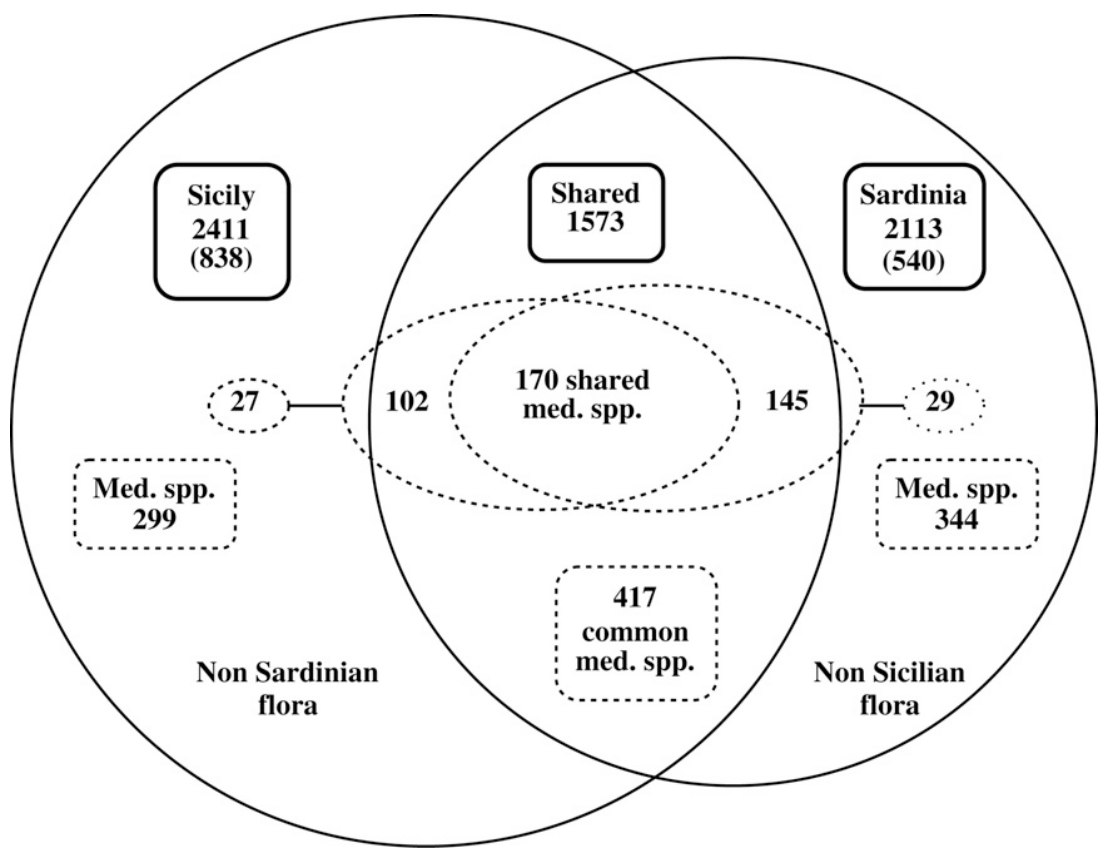

Graphic 1. Total flora and medicinal flora of Sicily and Sardinia.

mainly the medical doctors and clergymen who made use of these books and divulged their content.

\subsection{Sardinia-cultural history and traditional medicine}

Sardinia (Ichnusa, Sandaliòtis or Sardò for the ancient Greek (Lilliu, 1967)) is the second largest island of the Mediterranean. The highest elevation lies in the Gennargentu massive with $1834 \mathrm{~m}$ a.s.l. The colonisations that created new homes, new human and cultural perspectives typical of Sicily and Magna Graeca did not occur to that extent in Sardinia. The colonisations of Sardinia almost exclusively had the intention to exert political and military power and had an exploitive character. Compared to Sicily the colonizers left only few cultural and ethic-ethnical transformations and potentiations (Lilliu, 1967).

Characteristic for Sardinia is the Nuraghe Civilization, which flourished from the chalcolithic period until the Roman Conquest (240 BC). The Nuraghe is a conical stone tower up to 20 meters in height and built from huge single blocks weighing up to several tons. It is not entirely clear what role the Nuraghi played but one of the obvious and most discussed purposes is that they served to ward off looters and invaders such as the Phoenicians (1200 BC onwards) and the Punicians (500 BC onwards). As a result of the Punic wars, Sardinia as well as Sicily became Roman provinces.

Wagner (1950) speaks of Sardinian dialects and identifies “Logudorese" as the most conserved form. He argues that once Sardinian was more homogenous and that the different influences gave rise to what others identify as languages of their own right such as Gallurese, Nuorese, Sassarese, Campidanese and Logudorese.

After the Second World War Sardinia was defined as the most underdeveloped region of Europe (Lussu, 1951). Still in this period the economic basis of the large part of the population was subsistence agriculture and nomadic pastoralism. Traditional medicine was the main health-care system until the Second World War and is conserved until nowadays by the elder generations (c.f. Atzei, 2003, p. xv et seqq.).
Traditional medicine comprises empirical as well as magical believes and practices. One of the most widespread cultural syndromes worldwide treated by a magical approach is "S'ogu liau" ("il malocchio" in Italian). It still is a common opinion that everybody has a potential to release the "aggression of the eye" or "evil eye". In the province of Cagliari people say that those who transmit the evil eye have the goat in the eye, i.e. the eye of the devil. Generally one starts to be a potential carrier of the "ogu liau" with the onset of adolescence (Cossu, 1996, p. 60). "S'ogu liau" derives from desire, admiration and jealousy and can be released by adult persons of either sexes and affect anybody (Cossu, 1996, p. 61). In any case, it is an instant, a moment difficult to control, which causes the crisis; it is the encounter of the looks, more precisely those of the pupil. Different therapeutic and preventive rituals do exist as for instance wearing the eye of Santa Lucia (opercula of the sea-snail genus Turbo). It is generally a woman who received the gift to cure with "brebus" (esorcistic prayers) and Christian prayers like the "Pater Noster" and the "Ave Maria" from a female relative of her own family. The symptoms include loss of vital spirit, loss of appetite, a general feeling of weakness and death may be the ultimate outcome. During the diagnosis and cure a hand full of wheat or barley grains are thrown into a bowl filled with water. The resulting air bubbles confirm that there was a bad energy (spirit) present and meanwhile symbolizes its extrusion. Furthermore, salt is sprinkled and olive oil, stones, horn of the moufflon, deer or ox, carbon and paper may be implemented.

Malaria was endemic to Sardinia and known since the invasion of the Phoenicians who are thought to have introduced the parasite. The last cases are recorded for the years 1948-1950 (Istituto Superiore di Sanità, 2001).

Until the year 1626 the main instrument of reference for the medical doctors in Sardinia was Matthioli's edition (1568) of "De Materia Medica". Afterwards, the Faculty of Medicine, which was following the Spanish school, adopted an edition of the opera translated and commented in Castilian by Laguna (Amat di San Filippo, 1990, p. 206). 


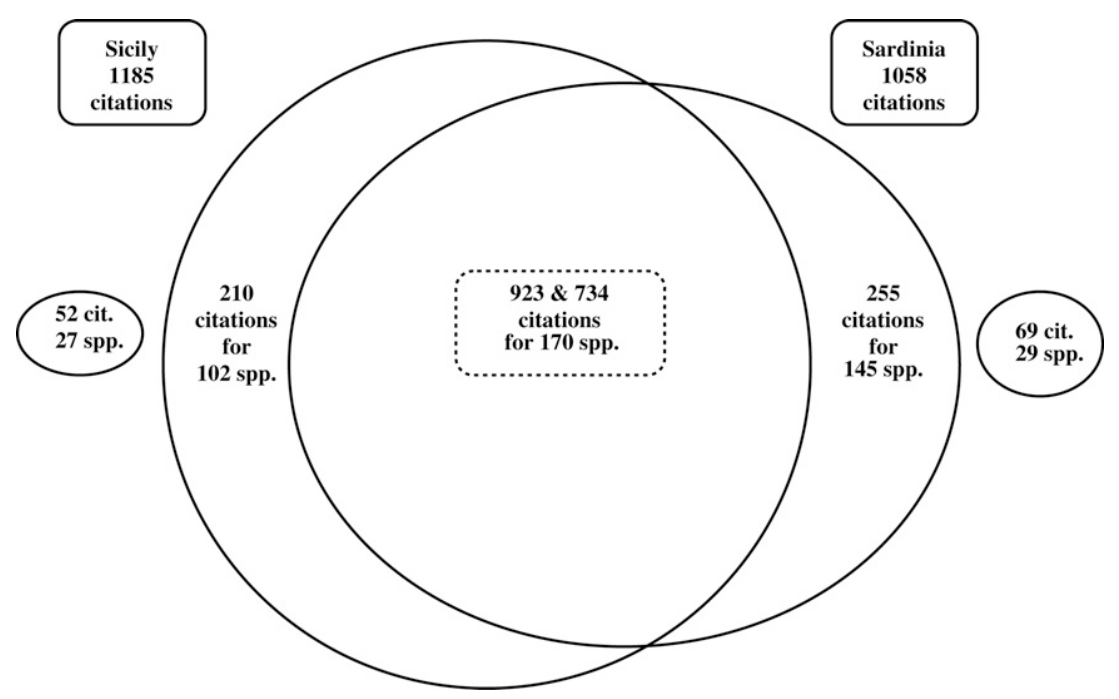

Graphic 2. Citations of medicinal plants in Sicily and Sardinia.

\subsection{Sicily-cultural history and traditional medicine}

Sicily is the largest of all Mediterranean Islands. The highest peak of the island is the Monte Etna, a volcano rising up to $3300 \mathrm{~m}$ a.s.l. The ancient tribes of Sicily (Siculi, Sicani, Elimi) were quickly absorbed when the Greek began to colonize Sicily and southern Italy to form Magna Graeca (750 BC). After the annexation by the Roman Empire (200 BC) Sicilian cities conserved Hellenistic structures and typology pertaining their Greek culture until Christianisation (200 AD) (La Biblioteca di Repubblica, 2005, p. 56). Therefore, in Sicily, which was among the epicentre of Greek culture, the Greek language continued to be lingua franca even under Roman patrimony. Now, Sicilian is considered a language of its own, which is spoken in the southern part of the peninsula of Italy (Calabria and Salento) and Sicily (Lo Piparo, 1990).

After the fall of the Roman Empire (400 AD) Vandals and Ostrogoths invaded and conquered Sicily and after 535 AD Sicily became province of the Byzantine Empire until ca. 1040. In the following the Arab and Spanish presence in Sicily were those who left most cultural, social, and economic traces. The Arabs introduced technical innovations into agriculture abandoning Roman monoculture.

Malaria was endemic to Sicily and eradicated only after the Second World War.

Hippocrates already described the symptoms of malaria, and the Athenian army was taken by malaria when they were couching in a swampy area trying to conquer Syracuse in 413 BC (Valenti and Tore, 1988, pp. 24-43). De Materia Medica and especially the edition commented by Matthioli was the fundamental text of pharmacology until the 18th century throughout the Italian peninsula (Cosmacini, 1997, p. 264).

Pitrè (1896) refers that besides the medical doctors and the pharmacists the barbers had a sort of a medical status operating blood-letting, cauterizations, opening of abscesses and that they were frequented in case of luxations, fractures, extraction of teeth, and above all venereal diseases like syphilis. Another person frequently located was the "erbaiuolo" (herbalist). Pitrè writes: "The herbalist suggests the juice of chicory (Cichoria sp.), sowthistle (Sonchus sp.), decoction of mallow (Malva sp.), marshmallow (Althaea sp.), barley (Hordeum vulgare L.), Bermuda grass (Cynodon dactylon Pers.), almond milk (Amygdalus dulcis Mill.), "canapuccia" (drink made from Cannabis sativa L. seeds), and a drink made from melon seeds (Cucumis sp.)". The shop of the herbalist is covered with bundles of herbs like henbane (Hyoscyamus niger $\mathrm{L}$.), mallow (Malva sp.) and sedum (Sedum telephium L.) as well as the herbs to bathe like rosemary (Rosmarinus officinalis L.), oregano (Origanum sp.) and thyme (Thymus sp.), which serve for the first bath of the newborn as well as for other stimulating baths.

\section{Methodology}

\subsection{Total flora}

The total flora (angiosperms, gymnosperms and pteridophyta) of Sardinia and Sicily were assessed based on "An annotated checklist of the Italian Vascular Flora" (Conti et al., 2005) and the "Updating of the checklist" (Conti et al., 2006), excluding neophytes and infraspecific taxa from the floral list. For the classification of the plant families the APG II (2003) was followed. Old world crop species, which have been introduced to these regions millennia ago, were included. We counted a total of 2411 species for the territory of Sicily (including the surrounding islands) listing 2352 angiosperms, 11 gymnosperms and 48 pteridophyta. For the territory of Sardinia we counted a total of 2113 species comprising 2056 angiosperms, 9 gymnosperms and 48 pteridophyta. According to Conti et al. (2005) Sardinia houses slightly more that 200 endemic species, while Sicily is home to about 230 endemic species.

\subsection{Medicinal flora}

We performed a thorough literature search on traditional medicinal plant usage in Sicily (Map 1) and Sardinia (Map 2). A large part of these studies were published in local journals in Italian. We gathered 15 publications referring to medicinal plant use in Sardinia including 17 field-study sites and 19 publications reporting medicinal plant use in Sicily including 37 field-study sites. Plant species for which a medicinal usage was mentioned were pooled in a database indicating the frequency of independent studies citing a medicinal use. Since especially earlier works did not supply plant lists with frequency of citations we ignored use-report counts of later works in order to facilitate the metaanalysis. According to the indications and uses reported in the various studies we defined use-categories wherein we grouped and counted the citations per plant species (c.f. Leonti et al., 2001). 


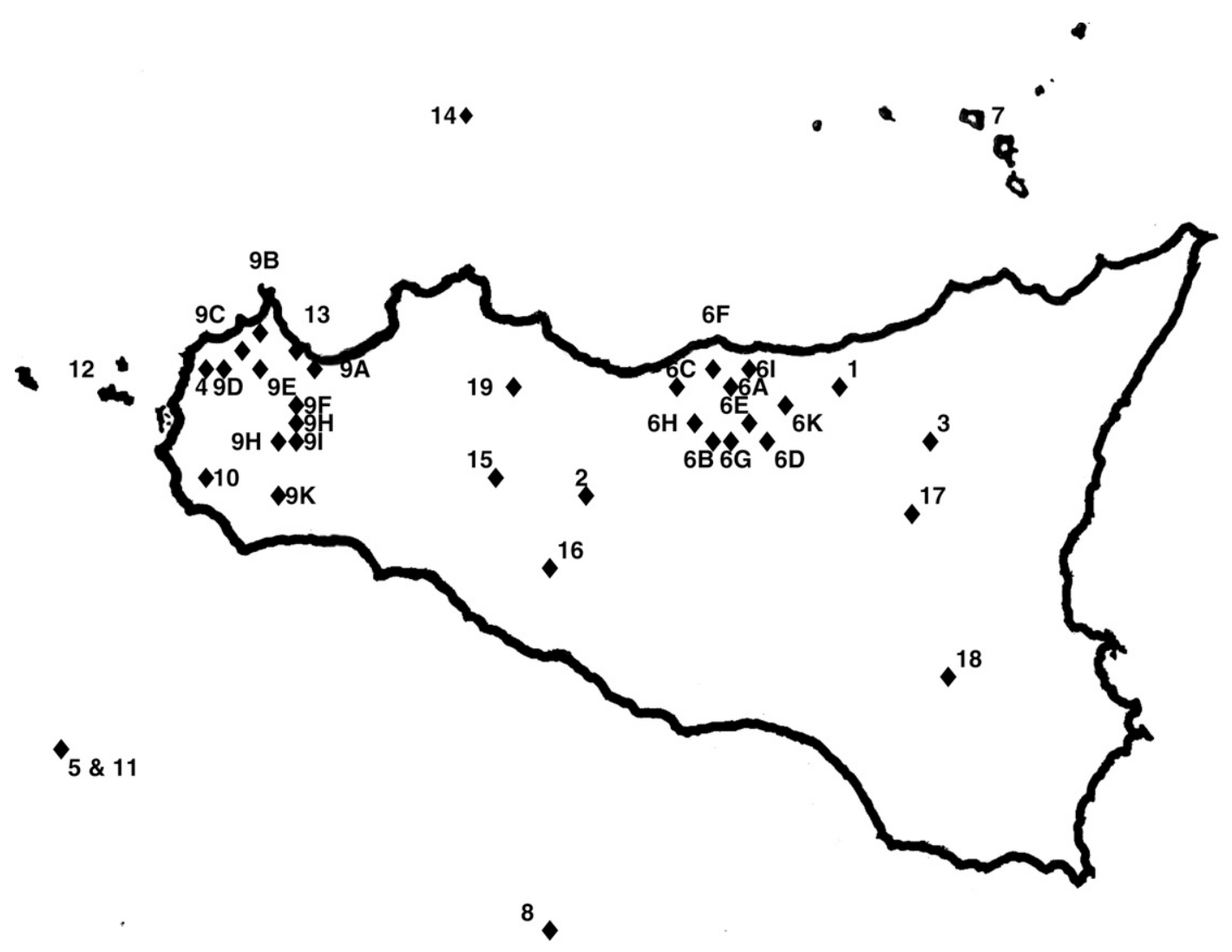

Map 1. 1: Mistretta; Messina (Lentini and Raimondo, 1990), 2: Mussomeli; Caltanissetta (Amico and Sorge, 1997), 3: Cesarò; Messina (Barbagallo et al., 1979), 4: Erice; Trapani (Lentini and Aleo, 1991), 5: Pantelleria; Trapani (Galt and Galt, 1978), 6A-K: Madonie, Palermo (Raimondo and Lentini, 1990), 7: Eolie, Messina (Lentini et al., 1995), 8: Pelagie, Agrigento (Lentini et al., 1996), 9A-K: Trapanese; Trapani (Lentini, 1987), 10: Mazara del Vallo; Trapani (Lentini et al., 1987-1988), 11: Pantelleria; Trapani (Lentini et al., 1996), 12: Egadi; Trapani (Lentini et al., 1997), 13: Riserva Naturale Dello Zingaro; Trapani (Lentini and Mazzola, 1998), 14: Ustica; Palermo (Lentini et al., 1994), 15: Bivona; Agrigento (Catanzaro, 1970), 16: Sant'Angelo Muxaro; Agrigento (Lentini, 1996), 17: Bronte; Catania (Arcidiacono et al., 1999), 18: Monterosso Almo; Ragusa (Napoli and Giglio, 2002), 19: Mezzojuso; Palermo (Ilardi and Raimondo, 1992).

Therefore, a single study may account for one citation of a plant species per category of use. Several studies included are limited to a list of medicinal species without indicating a specific medicinal usage. Therefore, the citation frequency may exceed the summed up citations per category of use per plant. For either island the 15 species or species-complexes with most citations are represented (Table 1: Sicily; Table 2: Sardinia) indicating the number of citations per category of use. In the following the detailed uses of the top 15 species of either islands are specified and presented in chapters entitled after De Materia Medica, paying tribute to Dioscorides. The first line reports the plant species as identified by Berendes (1902) while eventual changes of the binomial plant names are reported in brackets. The first paragraph presents the uses reported by Dioscorides, while the second one summarises the uses from the ethnobotanical studies of Sicily and Sardinia.

Table 1

Most cited plants in Sicily (max. possible citations: 37 ).

\begin{tabular}{|c|c|c|c|c|}
\hline Plant species & Family & Uses & Part used & Cit. \\
\hline Laurus nobilis L. & Lauraceae & GA (25) RESP (2) & Leaves & 33 \\
\hline Borago officinalis L. & Boraginaceae & GA (18) UR (15) RESP (3) DERM (2) & Herb & 33 \\
\hline Cynodon dactylon $\mathrm{L}$. & Poaceae & UR (22) GA (7) DERM (2) & Root & 30 \\
\hline Malva sylvestris L. and M. nicaeensis All. & Malvaceae & GA (15) DERM (9) UR (6) RESP (3) & Herb, flowers, roots & 29 \\
\hline Opuntia ficus-indica L. & Cactaceae & UR (19) GA (11) SK-MU (8) DERM (7) & Flowers, cladodes & 25 \\
\hline Parietaria diffusa $\mathrm{L}$. & Urticaceae & UR (11) DERM (9) GA ( 7) SK-MU (3) RESP (2) & Herb & 25 \\
\hline Urtica membranacea Poir. & Urticaceae & GA (13) DERM (10) & Herb, root & 24 \\
\hline Rubus ulmifolius Schott. \& Rubus fruticosus L. & Rosaceae & $\operatorname{DERM}(17) \mathrm{GA}(7)$ & Leaves & 23 \\
\hline Ruta chalepensis L. & Rutaceae & GA (17) SK-MU (5) GYN (3) NERV (2) & Leaves & 23 \\
\hline Artemisia arborescens L. & Asteraceae & GA (11) DERM (7) FEV (3) & Herb & 20 \\
\hline Cichorium intybus L. & Asteraceae & GA (19) UR (4) & Herb & 18 \\
\hline Foeniculum vulgare Mill. & Apiaceae & GA (13) UR (3) RESP (3) GYN (2) & Seeds, herb, roots & 18 \\
\hline Calamintha nepeta Savi & Lamiaceae & GA (4) DERM (4) SKMU (2) & Herb & 17 \\
\hline Asphodelus ramosus L. and Asphodelus fistulosus L. & Asphodelaceae & DERM (10) & Root & 17 \\
\hline Inula viscosa (L.) Aiton & Asteraceae & DERM ( 8$)$ & Leaves & 16 \\
\hline
\end{tabular}

GA, gastrointestinal disorders; UR, urological problems; RESP, respiratory complaints; DERM, dermatologic problems; SK-MU, skeleto-muscular disorders; CARD-VASC, cardio-vascular application; FEV, fever; EAR, problems of the ear; NERV, headache, toothache, analgesic; GYN, gynaecology. 
Table 2

Most cited species in Sardinia (max. possible citations: 17).

\begin{tabular}{|c|c|c|c|c|}
\hline Plant species & Family & Most frequent uses & Part used & Cit. \\
\hline Malva sylvestris $\mathrm{L}$. & Malvaceae & GA (16) DERM (14) RESP (8) UR (6) NERV (3) & Herb, root, flower, fruit & 17 \\
\hline Pistacia lentiscus L. & Anacardiaceae & DERM (9) GA (6) RESP (3) SK-MU (3) & Resin, fruit, leaves, roots, & 15 \\
\hline Smilax aspera L. & Liliaceae & UR (8) GA (7) SK-MU (5) DERM (5) RESP (3) NERV (3) & Root, leaves, fruits & 15 \\
\hline Parietaria judaica L. & Urticaceae & GA (10) UR (8) DERM (7) NERV (5) RESP (3) & Aerial parts & 14 \\
\hline Rosmarinus officinalis L. & Lamiaceae & GA (10) RESP (7) DERM (5) NERV (4) SK-MU (3) UR (3) & Aerial parts & 14 \\
\hline Laurus nobilis L. & Lauraceae & GA (13) SK-MU (5) RESP (5) DERM (2) & Leaves, fruits & 14 \\
\hline Sambucus nigra L. & Caprifoliaceae & EYE (8) DERM (6) GA (4) SK-MU (3) NERV (3) & Leaves, flowers & 12 \\
\hline Arbutus unedo L. & Ericaceae & GA (10) DERM (6) CARD-VASC (3) UR (3) & Roots, leaves, fruits, bark & 13 \\
\hline Marrubium vulgare $\mathrm{L}$. & Lamiaceae & RESP ( 7) FEV (5) SK-MU (4) GA (3) NERV (3) DERM (2) GYN (2) & Aerial parts & 12 \\
\hline Myrtus comunis L. & Myrtaceae & GA (7) RESP (7) DERM (5) & Leaves, fruits & 12 \\
\hline Olea europaea L. & Oleaceae & GA (7) CARD-VASC (7) DERM (7) FEV (4) EAR (3) & Oil, leaves, bark & 12 \\
\hline Borago officinalis L. & Boraginaceae & RESP (9) UR (4) DERM (4) GA (3) NERV (2) & Aerial parts & 11 \\
\hline Artemisia arborescens L. & Asteraceae & GA (10) RESP (5) DERM (2) SK-MU (2) & Aerial parts & 11 \\
\hline Asphodelus ramosus L. and Asphodelus fistulosus L. & Asphodelaceae & DERM (10) RESP (4) & Rhizome & 11 \\
\hline Ruscus aculeatus L. & Liliaceae & UR (5) SKMU (4) CARD-VASC (3) NERV (2) & Rhizome, fruits, leaves & 11 \\
\hline
\end{tabular}

GA, gastrointestinal disorders; UR, urological problems; RESP, respiratory complaints; DERM, dermatologic problems; SK-MU, skeleto-muscular disorders; CARD-VASC, cardio-vascular application; FEV, fever; EAR, problems of the ear; NERV, headache, toothache, analgesic; GYN, gynaecology.

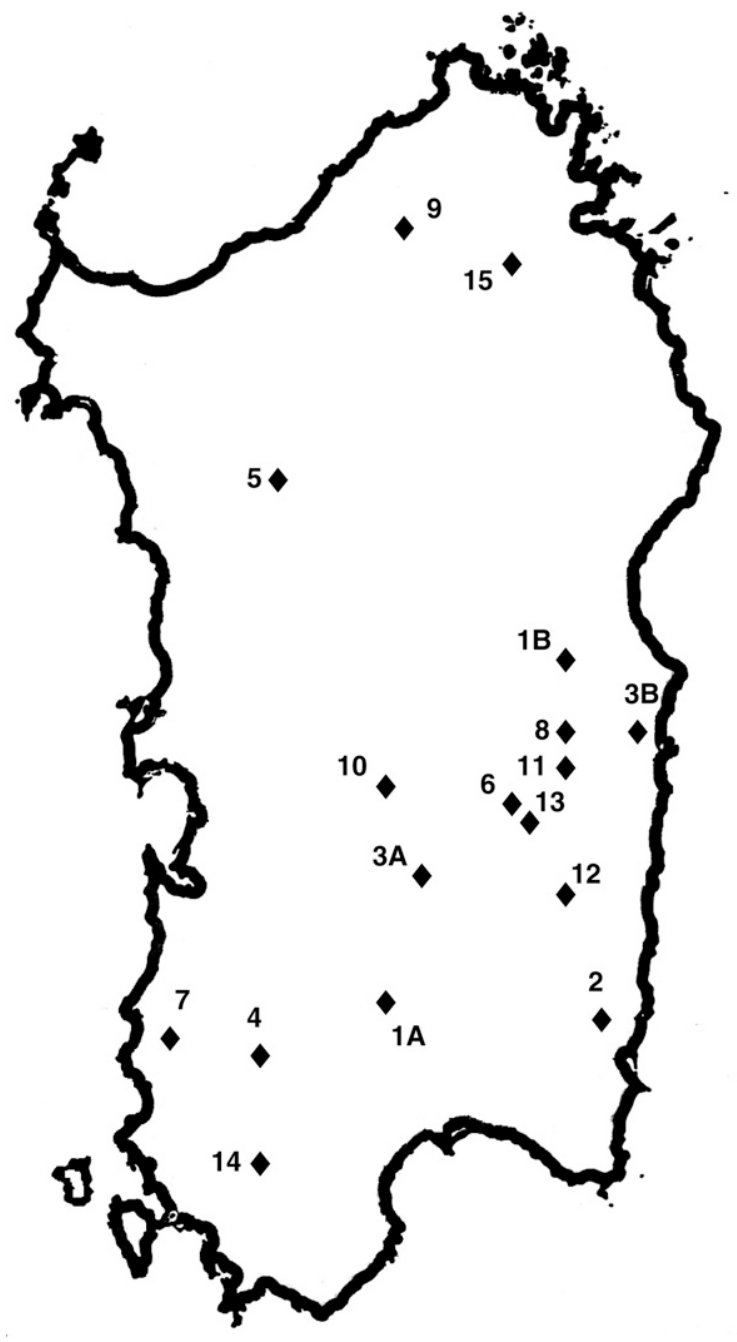

Map 2. 1A: Campidano; Cagliari (Bruni et al., 1997), 1B: Urzulei; Ogliastra (Bruni et al., 1997), 2: Sarrabus, Cagliari (Palmese et al., 2001), 3A: Escolca; Cagliari (Loi et al., 2005), 3B: Lotzorai; Ogliastra (Loi et al., 2005), 4: Marganai; Carbonia-Iglesias (Ballero and Fresu, 1991), 5: Monteleone; Sassari (Ballero and Poli, 1998), 6: Seui; Ogliastra (Ballero and Fresu, 1993), 7: Fluminimaggiore, Carbonia-Iglesias (Ballero et al., 2001), 8: Villagrande Strisaili, Ogliastra (Loi et al., 2004), 9: Tempio Pausania, Olbia-Tempio (Ballero et al., 1997), 10: Laconi; Oristano (Ballero et al., 1997), 11: Arzana; Nuoro (Ballero et al., 1994), 12: Perdasdefogu; Ogliastra (Ballero et al., 1997) 13: Ussassai; Ogliastra (Ballero et al., 1998), 14: Carbonia-Iglesias (Atzei et al., 1994), 15: Gallura; Olbia-Tempio (Atzei et al., 1991).

\subsection{Statistics}

We use a $\chi^{2}$-test for a cross-cultural analysis on the basis of the effectively shared and non-shared medicinal species and calculate a $95 \%$ confidence interval. The number of shared medicinal plants to be expected if the selection had been done at random serves as a reference value to exemplify the cultural concordance.

In order to test for significantly overused and underused plant families among the medicinal flora of Sardinia and Sicily we apply a binomial approach recently introduced into ethnobotanical analysis by Bennett and Husby (2008). This approach builds up on the questions addressed by Moerman and colleagues (Moerman, 1991, 1996; Moerman et al., 1999) but substitutes the regression analysis by a more accurate binomial method permitting inferential statistics.

\section{Results and discussion}

\subsection{Comparison of the floras}

The two islands share 1573 plant species: 1142 eudicots (72.6\%) 373 (23.6\%) monocots, 6 magnoliidis, 3 ceratophyllales, 9 gymnosperms and 40 pteridophyta. Sicily houses 838 species (638 eudicots (76.1\%), 184 monocots (22.0\%), 5 magnoliids, 1 ceratophyllales, 2 gymnosperms and 8 pteridophyta) not present in Sardinia while Sardinia harbours 540 species (437 eudicots (80.9\%) and 92 (17.0\%) monocots, 1 magnoliid, 2 ceratophyllales and 8 pteridophyta) not occurring natively in Sicily (Graphic 1 ). In the following we use the term "non-Sardinian flora" to refer to the species present in Sicily but not in Sardinia, while the term "non-Sicilian flora" includes the species present in Sardinia but not in Sicily.

The null hypothesis that the non-Sicilian angiosperms and the non-Sardinian angiosperms have an equal portion of eudicots and monocots was refused at $\alpha=0.05$ with a $\chi^{2}$ value of 4.95 . This might be the reflection of a more continental distribution of geophytes.

\subsection{Comparison of the medicinal floras}

In total the flora common to both islands (1573) accumulate 417 medicinal species while the non-Sicilian flora (540) counts with 29 medicinal species and the non-Sardinian flora (838) with 27 medicinal species. Crucial for our analysis are the 170 species (Tables 9a-c, supplementary data) included in the medicinal flora of both islands (Graphic 1 ). 
The data gathered in 17 field-study sites in Sardinia altogether cite 344 native medicinal plant species from 85 families, while 31 plant families feature no medicinally used species. Of the 344 medicinal species 315 species are native to Sicily as well. Besides, 38 neophytes are also used but not included in the comparison. Altogether, the 344 native plants received 1058 citations, while the neophytes account with 75 citations. The 315 species present also in Sicily sum up to 989 citations and the ones absent from Sicily sum up to 69 citations (Graphic 2).

The data gathered in 37 field-study sites in Sicily altogether cite 299 native medicinal plants from 73 plant families, while 36 plant families are not used as a source for medicinal species. Of the 299 medicinal species 272 are native also to Sardinia. The additional 28 neophytes adopted by traditional medicine are not included in the comparison. Overall, the 299 native species account with 1185 citations and the neophytes with 52 . The 272 species present as well in Sardinia count with 1133 citations, while those absent from Sardinia were cited 52 times (Graphic 2).

By far the most important medicinal species regarding the number of citations are those 170 plant species used on both islands, which got 923 (Sicily) plus 734 (Sardinia) references and summing up to 1657 citations or $74 \%$ of all citations while the remaining 303 species count with $26 \%$ of all citations.

Looking at the 15 most frequently cited species in Sicily gastrointestinal conditions stand out as the most important category of use (167 citations, or $45 \%$ ). The second most frequently cited category of use with nearly half as many citations is that of dermatological problems ( 85 citations, or $23 \%$ ) closely followed by urological disturbances (80 citations, or $21 \%$ ). Respiratory ailments do not seem to be an important issue (to be treated with medicinal plants) counting with just 13 citations or $3.5 \%$.

Doing the same sort of count with the 15 most cited species in Sardinia we get a somewhat different picture. Gastrointestinal (106 citations, or $28 \%$ ) and dermatological (84 citations, or $22.5 \%$ ) citations are almost of the same importance, while citations for urological conditions (37 citations, or 10\%) are far less frequent while those for respiratory ailments (63 citations, or 17\%) are far more numerous that those in Sicily. Formation of urinary stones is a common disorder of people living in areas with unreliable water resources, the so-called stone-belt (Lev and Dolev, 2002), which could explain the need for diuretics in Sicily. To get a complete picture one should however count up the citations made for all species.

The only important application of a neophyte is the use of Opuntia ficus-indica L. petals to treat urological problems in Sicily. To treat kidney colic with flowers of Opuntia ficus-indica is already referred to by Pitrè (1896). The arrival of Opuntia ficus-indica has been embraced with great enthusiasm in Sicily, as it has become both, an important fruit crop and medicinal plant.

Endemic species which are included in the medicinal flora of Sardinia are: Cymballaria muelleri (Moris) A. Chev., Scrophularia trifoliata L., Glechoma sardoa (Bég.) Bég., Aristolochia thyrrenia E. Nardi and Arrigoni., and Santolina insularis (Genari ex Fiori) Arrigoni. Endemic species included in the medicinal flora of Sicily are: Sideritis italica (Mill.) Greuter \& Burdet and Senecio lycopifolius Desf. All these species are of minor importance and with the exceptions of Santolina insularis, Scrophularia trifoliata and Sideritis italica cited in just one ethnobotanical study.

\subsection{Comparison of the 15 most cited medicinal species of either islands with Berendes (1902) translation of Dioscorides' De Materia Medica}

The confrontation of the specific uses mentioned in De Materia Medica with those reported in the ethnobotanical studies of Sardinia and Sicily shows a high agreement, especially for the cat- egories of use. It were, however, the minor but specific uses like Asphodelus spp. to treat burns and chilblains, Artemisia sp. against malaria, Foeniculum as an eye remedy, Pistacia lentiscus against bad breath and as an anti-sudorific, Ruscus against headaches, Rubus spp. against gingivitis, Calamintha sp. against intestinal parasites, as a vulnerary, against bites of venomous animals and to induce labour, Myrtus as an anti-sudorific, Inula sp. as a haemostatic, that raised our eyebrows and prompted us to undertake such an investigation. Less congruence were found with Laurus and especially with Arbutus and Smilax. The strawberry tree might in fact be an autochthonous Sardinian element while the uses of Smilax seem to have been introduced to Europe after La Conquista as a surrogate for Sarsaparilla (Berendes, 1902).

Among the species not included in Berendes' translation is one prominent one: Borage (Borago officinalis L.). Borage is widely used in Sicily as a diuretic vegetable, which has as well emollient properties on the intestine. In Sardinia the most cited category of use for Borage is that of respiratory ailments like cough and bronchitis. However, Matthioli (1568) as well as Laguna (1555) include a chapter on borage. Matthioli (1568) writes in chapter CXXX, pp. 1244-1248 (quarto libro) in his comments on Buglosson (chapter 127 in Berendes): The ones that take into account history will come to the conclusion that the "Buglossa" of Dioscorides is the true borage of our home gardens (notwithstanding Dioscorides' affirmation that the plant thrives in the lowlands and is gathered in July). Then he perambulates in a cumbersome and contradictory explanation why this is the case citing Avicenna and Apuleio. He further writes that those who consider Buglosson being a species of Echium are not using their intellect. Finally Matthioli divides Buglosson into three species: "Buglossa vera" (borage), "Buglossa volgare" and "Another buglossa with black flowers". Laguna (chapter 129) follows Matthioli saying that Buglosson is nothing else than what we call "boraja" in Castilian, but omitting Matthioli's circular argumentation.

Apparently rosemary (Rosmarinus officinalis L.) has not received much attention by Dioscorides. Matthioli (1568) comments in his Discorsi (terzo libro, Cap. LXXXIII, pp. 831-832) that our "Rosmarino coronario" is known by everybody throughout Italy and planted in the gardens and vineyards because it is not only medicinal but as well used in the cuisine. Rosemary serves against the cold problems of the stomach, against reflux and vomiting. It is good for those who have spleen and liver problems. Furthermore, in form of a lavation it serves against all the cold problems of the head like epilepsy, stupor and somnolence. Taken in form of powder every day it also arrests the white flow of the women.

In general, however, De Materia Medica treats the singular species comprehensively including more specific indications and preparations than reported below. The synthesis of all the Sardinian and Sicilian indications and explanations reported in the various publications for any single plant taken together do not get even close to the comprehensiveness, professionalism and accuracy of De Materia Medica.

Asphodelos (II book, chapter 199): Asphodelus racemosus Link (=Asphodelus ramosus L.) and Asphodelus albus Mill.

Apart from the treatment of several inflammatory dermatologic conditions Dioscorides reports that "if oil is scalded in the gauged roots (of Asphodelos) it will be good against chilblains and burns". Its roots cure cough if taken in wine.

A particularly specific congruence can be observed with the usage of the roots of Asphodelos: While in Sardinia the use of the roots of Asphodelus ramosus L. against chilblains dominates, in Sicily the roots of (Asphodelus ramosus L. and Asphodelus fistulosus L.) are used as a cutaneous disinfectant, against burns and to treat respiratory ailments. 
Seris (II book, chapter 159): Cichorium intybus L.

After Dioscorides chicory is astringent, cooling and good for the stomach. Boiled it helps against diarrhoea if taken with vinegar; more the wild ones which are more salubrious because when eaten they are an exquisite remedy against a weak and heated stomach.

In Sicily wild chicory is eaten and praised for its refreshing and cooling action on the gastrointestinal tract. To season boiled leaves of chicory with vinegar is still a common recipe in Sardinia.

Helxine (IV book, chapter 86): Parietaria judaica L.

"The leaves have a cooling astringent property and therefore heal zoster, swellings, burns, . . inflammations and oedema", while its juice is good against chronic cough and helps against inflamed tonsils.

In Sicily its paramount use is that of a diuretic and against affection of the urinary tract while the treatment of dermatologic afflictions like furuncles comes second. Another important category of use in Sicily is that of light gastrointestinal disturbances. As well in Sardinia the uses against disorders of the gastrointestinal tract like gastritis and as a diuretic are more frequent than uses for dermatologic conditions.

\section{Schinos (I book, chapters 50, 51, 89, 90): Pistacia lentiscus L.}

Mastic oil is astringent and is effective against stomach-ache and dysentery. Mastic resin is used with benefit against cough. The oil of the ripe fruits is effective against scabies of the draft cattle and dogs...it retains sudor. Chewing the resin fortifies the teeth ridge and confers fragrance to the oral cave.

The uses in Sardinia match those of De Material Medica largely. The resin is used against diarrhoea and stomach-ache, as a vulnerary, the oil of the fruits against scabies and a fumigation of the resin against ticks, the infusion of the leaves against cough and even the use against bad breath and as an anti-sudorific are reported. The anti rheumatic uses are not described by Dioscorides while he additionally describes the uses against uterus bleeding.

Malache (II book, chapter 144): Malva sylvestris L. and Malva rotundifolia L. (=Malva neglecta Wallr.)

It is good for the belly... and it is salubrious for the bowels and the bladder. The boiled and pounded leaves together with oil cure burns and zoster-like inflammations. A hip-bath taken in the decoction soothes the uterus.

In Sicily Malva sylvestris L. and Malva nicaeensis All. and in Sardinia Malva sylvestris and Malva parviflora L. are used most frequently against gastrointestinal pains as a laxative and as a diuretic. A decoction of the herb is used to treat gingivitis while cataplasms are used to treat furuncles and ulcerous wounds.

Myrsyne agria (IV book, chapter 144): Ruscus aculeatus L.

The leaves and the fruits, taken with wine, are diuretic, have the power to promote the menstrual period, and to crash bladder stones. They cure jaundice, dysuria and headaches. The decoction of the root taken with wine has the same properties. The young shoots are eaten as a vegetable like asparagus. They are somewhat bitter and diuretic.

In Sardinia the roots are used as a diuretic and the fruits against joint pains, sciatica, and against neuralgia and to treat varices.

Elaia (I book, chapters 136, 137 and 139): Olea europaea L.
Dioscorides describes the use of olive oil as an excipient in the manufacture of ointments. Furthermore he praises its astringent powers "it is light for the stomach, cures wounds and strengthens the teeth... as well it retains sudor. The liquid, which is excreted when green wood is burned, heals impetigo contagiosa, scabies and lichen. Anti-hypertension activities of the leaves are not reported by Dioscorides.

In Sardinia olive oil is most frequently used as a laxative and to treat burns.

Peganos (III book, chapter 45): Ruta graveolens L.

Eaten as well as taken in form of an infusion rue stops diarrhoea and helps against a bloated stomach. It induces the menstrual period and kills the fruit of womb. It works as well against sciatica, pain of the joints and periodic chills. Boiled and drunk it expels the tapeworm.

The main use of Ruta chalepensis L. in Sicily is to expel worms. Other uses are to treat rheumatic pains and sciatica. It is the only plant that received more than 2 citations for its use in women's medicine: once it is cited to treat dysmenorrhoea and twice as an abortifacient.

Batos (IV book, chapter 37): Rubus tomentosus Borkh., Rubus caesius L., Rubus fruticosus L.

A decoction of the twig tops works against diarrhoea and soothes menstruations. Chewing the leaves strengthens the gums and cures thrush. Leaves used as a wrapper stop abscesses and cure favus.

The main application in Sicily of Rubus ulmifolius Schott. is against furuncles and gingivitis. An infusion of the leaves is used against diarrhoea.

Daphne (I book, chapter 106): Laurus nobilis L.

Dioscorides writes that laurel leaves have warming and emollient properties, and that's why hip-baths of the decoction thereof suit to treat uterus and bladder problems. The green leaves are slightly astringent and applied in triturated form they heal bee and wasp stings. The decoction taken internally, however, burdens the stomach and provokes vomiting. The bark of the root crushes the (kidney) stones, kills the fruit (of womb) and is medicinal for liver troubles.

Laurel leaves are the most frequently reported medicinal agent in Sicily to treat stomach-ache and indigestion. The practice to use laurel leaves as a digestive might be reflected in Dioscorides' annotation that the roots' bark suits for liver problems but all together it is an ambiguous analogy.

Komaron (I book, chapter 175): Arbutus unedo L.

Dioscorides looses few words to treat the strawberry tree. He writes that the fruits are edible but harmful to the stomach and causing headache.

While in Sicily the medicinal use of the strawberry tree is inconsiderable in Sardinia the decoction of the leaves are used to treat diarrhoea, intestinal pains and is used as well as a vulnerary.

Smilax tracheia (IV book, chapter 142): Smilax aspera L.

Dioscorides writes that the leaves and the fruits are antidotes against deadly poisons. . . and that "... . people narrate that if a maceration thereof is given a newborn, it will not be affected by any kind of noxious agent". 
Berendes comments that in Italy and Greece the root of Smilax aspera L. has been used as a substitute for the American Sarsaparilla (Smilax officinalis Kunth) to treat syphilis.

In Sardinia the roots of Smilax aspera are used as a diuretic, as a hepatoprotective, against skin diseases and to treat rheum.

\section{Akte (IV book, chapters 171 and 172): Sambucus nigra L.}

The fresh tender leaves used as a compress together with roll barley relieves cutaneous inflammations and are a good remedy against burns and dog bites. The plant is diuretic and the leaves prepared as a vegetable drain the mucus and the bile.

In Sardinia the decoction of the leaves and flowers are used to treat eye infections while cataplasms of the leaves are used against erysipelas and epidermal ulcer. Internally the leaves are used as a spasmolytic.

Kalamintha (III book, chapter 37): Mentha tomentella Hoffmanns and Link. (=Mentha pulegium L.), Mentha gentilis L., Thymus calamintha Scop. (=Calamintha officinalis Moench).

Kalamintha is able to kill the tapeworm and intestinal worms“..."the finely chopped leaves...kill the embryo and promote the menstruation". "Cooked in wine and applied as a wrapper it turns dark scars white". "Internally and externally it helps in case of snake-bites".

Ethnobotanical studies in Sicily recorded uses of Calamintha nepeta Savi against intestinal parasites, as a vulnerary, against bites of venomous animals and to induce labour.

\section{Myrsyne (I book, chapter 155): Myrtus communis L.}

Dioscorides reports the fruits and the juice thereof against problems of the stomach and dermatologic conditions like abscess and eschar. The finely ground leaves are reported as a good means against humid ulcer and as an anti-sudorific.

Myrtle is an especially important plant in Sardinia as its fruits are macerated in alcohol and manufactured into the national liquor named "mirto" (myrtle). The ethnobotanical studies report uses of the leaves and the fruits as a digestive and as an agent to treat respiratory ailments (not mentioned by Dioscorides). Other citations refer to uses as a vulnerary, against haemorrhoids and to treat sweaty feet.

Akalyphe (IV book, chapter 92): Urtica urens L., Urtica pilulifera L., Urtica diocia $\mathrm{L}$.

Dioscorides mentions 2 varieties of nettle and lists the uses against divers dermatologic problems without referring to the use for the hair or against dandruff. Furthermore he reports that the leaves cooked together with mussels soothes the stomach, drives away flatulence and propel the urine. Cooked together with "ptisane" (potion made from barley porridge) it purifies the breast.

In Sicliy Urtica membranacea Poir. Urtica dioica L. and Urtica urens L. are used as a gastrointestinal purifier and anti-diarrhoeic. Leaves are used in form of a cataplasm against haemorrhoids and to prevent hair loss and dandruff.

Marathron (III book, chapter 74): Anethum foeniculum L. (=Foeniculum vulgare Mill.)

The herb and the seeds have the power to promote the secretion of milk. The decoction of the stalk is beneficial to those with kidney and bladder problems because it drives the urine. In cases of fever...it eliminates sickness and the burn of the stomach. The sun-dried juice of the stalks is used as an ingredient in eye remedies.

The field studies on traditional medicine in Sicily report first of all on the digestive, carminative and anti-acidity properties of the seeds and the stalk. Furthermore the diuretic action and the use against reddened eyes are mentioned. The use as an expectorant is not included in Dioscorides' work.

Absinthion, Absinthion talassion and Abrotonon (III book, chapters 23, 24, 26): Artemisia absinthum L., Artemisia maritima L., Artemisia abrotanum $\mathrm{L}$.

De Materia Medica specifies several Artemisia (Wermouth) species. Artemisia absinthum is warming, astringent, promotes digestion and the urine. It is a good agent against stomach-ache (Cap. 23). Artemisia maritima taken solely or cooked with rice and taken with honey kills the ascaris and roundworms and expels them readily (Cap. 24). Artemisia abrotanum. . . can be used for an unguent against shiver. . .is as well a remedy for inflamed eyes. . . and cooked with bruised grains of barley it opens swellings (Cap. 26).

Ethnobotanical studies of Sicily most frequently report digestive and vermifuge properties for Artemisia arborescens L. The second most important use category is that of dermatologic complaints such as furuncles, acne, eczema and varices. Once it is cited against fever and twice against malaria. In studies of traditional medicine in Sardinia Artemisia arborescens L. is referred against helminthiasis and against colics. Respiratory ailments are the second most important category of use, which does not find any parallel in De Materia Medica except from the indication against shortage of breath. As a febrifuge Artemisia arborescens L. is referenced once.

Prasion (III book, chapter 109): Marrubium vulgare L.

Dioscorides writes that the decoction of the leaves...together with honey is given those who suffer from tuberculosis, asthma and cough. . . and drains the phlegm form the breast. It is prescribed to the women in order to induce menstruation and to expel the placenta. The leaves together with honey as a cataplasm clean dirty abscesses. Moreover it dispels jaundice.

Sardinian studies most frequently report the uses for respiratory ailments such as cough, asthma and bronchitis as well as its mucolytic properties. Furthermore it is cited as a remedy against fever as a digestive and against hepatic problems, and to treat infections of the vagina, against abscesses and to treat rheum.

\section{Elenios (book I, chapter 27): Inula helenium L.}

Dioscorides states among other uses that the pounded and eaten leaves help those who suffer from haemorrhages.

In Sicily the most frequent use of Inula viscosa (L.) Aiton is that of a haemostatic.

Agrostis (IV Book, Chapter 30): Triticum repens L. (=Agropyron repens L.), Cynodon dactylon Pers.

The finely pounded roots agglutinate wounds...the decoction thereof acts against stomach-ache, urea problems, bladder ulcer and crushes the (kidney) stone.

It seems in Sicily "agrostis" is interpreted as Cynodon dactylon Pers. The roots of Bermuda grass are used against inflammations of the urinary and gastrointestinal tract, as a diuretic and against renal colic and kidney stones.

Libanotis (III book, chapter 79 (89)): Rosmarinus officinalis L. 
Table 3

Plant families overrepresented among the Sardinian medicinal flora.

\begin{tabular}{lrrrrrrr}
\hline Family & \multicolumn{1}{c}{$S$} & \multicolumn{1}{c}{$M$} & \multicolumn{1}{c}{$E$} & $M-E$ & $P \leq M$ & $P=M$ & $P \geq M$ \\
\hline Lamiaceae & 66 & 26 & 10.74 & 15.26 & 1.00 & 0.00 & 0.00 \\
Rosaceae & 51 & 18 & 8.30 & 9.70 & 1.00 & 0.00 & 0.00 \\
Urticaceae & 9 & 7 & 1.47 & 5.53 & 1.00 & 0.00 & 0.00 \\
Polygonaceae & 26 & 9 & 4.23 & 4.77 & 0.99 & 0.01 & 0.02 \\
Malvaceae & 20 & 7 & 3.26 & 3.74 & 0.99 & 0.02 & 0.03 \\
Solanaceae & 9 & 5 & 1.47 & 3.53 & 1.00 & 0.01 & 0.01 \\
Fagaceae & 8 & 4 & 1.30 & 2.70 & 1.00 & 0.02 & 0.03 \\
Oleaceae & 5 & 3 & 0.81 & 2.19 & 1.00 & 0.03 & 0.03 \\
Caprifoliaceae & 5 & 3 & 0.81 & 2.19 & 1.00 & 0.03 & 0.03 \\
Anacardiaceae & 2 & 2 & 0.33 & 1.67 & 1.00 & 0.03 & 0.03 \\
Rafflesiaceae & 2 & 2 & 0.33 & 1.67 & 1.00 & 0.03 & 0.03
\end{tabular}

$S$, species flora; $M$, medicinal species; $E$, expected medicinal species; $M-E$, residual; $P \leq M$, probability of $M$ or fever; $P=M$, probability of $M ; P \geq M$, probability of $M$ or more.

The kind of libanotis, which the Romans call rosmarinus has a warming property and its decoction cures jaundice (if drunk before exercise)

In Sardinia the decoction of rosemary leaves is used in the first place as a digestive, against hepatic problems and diarrhoea. Furthermore it is used to treat cough, asthma and bronchitis, and cutaneous problems like psoriasis and hair loss.

\subsection{Plant families over- and underrepresented in the pharmacopoeias: the binomial approach}

Generally, Asteraceae and Lamiaceae are overrepresented in holarctic ethnopharmacopoeias, while Poaceae, Cyperaceae and Orchidaceae are selected only rarely for medicinal purposes (Moerman et al., 1999). Different possible reasons for the under- and overrepresentation of certain plant families in ethnopharmacopoeias have been discussed (Stepp and Moerman, 2001, Leonti et al., 2003b).

The plant families significantly overused in Sicily and Sardinia at $\alpha=0.05$, are almost identical to each other: Lamiaceae, Rosaceae, Malvaceae, Urticaceae, and Solanaceae (Tables 3 and 5). There is one surprising difference: Asteraceae are not among the significantly overused plant families in Sardinia (216 species, 38 medicinal, 35.2 expected, 2.8 residual, $\mathrm{pM}$ or fever $=0.73, \mathrm{pM}=0.06$, $\mathrm{pM}$ or more $=0.33$ ). Still, the Asteraceae are the plant family providing most medicinal species in Sardinia.

As well, plant families underrepresented in the Sicilian and the Sardinian medicinal flora are almost the same with nearly identical ranking (ranked after $M-E$ ) (Tables 4 and 6). A reason for the low rank of the Plumbaginaceae can be named: The "Limonium" genus. There are 51 inventoried species in Sardinia and 41 in Sicily; almost every other bay has its own species of Limonium. One reason for the high ranking of the Urticaceae in Sardinia and Sicily is the few family members and that there are just two genera, which comprise species that folk taxonomically may be perceived on the genus level

Table 4

Plant families underrepresented among the Sardinian medicinal flora.

\begin{tabular}{lrrrrrrr}
\hline Family & \multicolumn{1}{c}{$S$} & \multicolumn{1}{c}{$M$} & \multicolumn{1}{c}{$E$} & $M-E$ & $P \leq M$ & $P=M$ & $P \geq M$ \\
\hline Potamogetonaceae & 17 & 0 & 2.77 & -2.77 & 0.05 & 0,05 & 1.00 \\
Orobanchaceae & 18 & 0 & 2.93 & -2.93 & 0.04 & 0.04 & 1.00 \\
Cyperaceae & 42 & 0 & 6.84 & -6.84 & 0.00 & 0.00 & 1.00 \\
Orchidaceae & 50 & 1 & 8.14 & -7.14 & 0.00 & 0.00 & 1.00 \\
Plumbaginaceae & 58 & 1 & 9.44 & -8.44 & 0.00 & 0.00 & 1.00 \\
Caryophyllaceae & 107 & 6 & 17.42 & -11.42 & 0.00 & 0.00 & 1.00 \\
Fabaceae & 208 & 20 & 33.86 & -13.86 & 0.00 & 0.00 & 1.00 \\
Poaceae & 206 & 8 & 33.54 & -25.54 & 0.00 & 0.00 & 1.00
\end{tabular}

$S$, species flora; $M$, medicinal species; $E$, expected medicinal species; $M-E$, residual $P \leq M$, probability for $M$ or fever; $P=M$, probability of $M ; P \geq M$, probability of $M$ or more.
Table 5

Plant families overrepresented among the Sicilian medicinal flora.

\begin{tabular}{lrrrrrrl}
\hline Family & \multicolumn{1}{c}{$S$} & \multicolumn{1}{l}{$M$} & \multicolumn{1}{l}{$E$} & $M-E$ & $P \leq M$ & $P=M$ & $P \geq M$ \\
\hline Asteraceae & 262 & 49 & 32.60 & 16.40 & 1.00 & 0.00 & 0.00 \\
Lamiaceae & 82 & 22 & 10.20 & 11.80 & 1.00 & 0.00 & 0.00 \\
Rosaceae & 67 & 16 & 8.34 & 7.66 & 1.00 & 0.00 & 0.01 \\
Malvaceae & 19 & 9 & 2.36 & 6.64 & 1.00 & 0.00 & 0.00 \\
Urticaceae & 8 & 7 & 1.00 & 6.00 & 1.00 & 0.00 & 0.00 \\
Papaveraceae & 24 & 7 & 2.99 & 4.01 & 0.99 & 0.02 & 0.02 \\
Solanaceae & 8 & 4 & 1.00 & 3.00 & 1.00 & 0.01 & 0.01 \\
Moraceae & 3 & 3 & 0.37 & 2.63 & 1.00 & 0.00 & 0.00 \\
Anacardiaceae & 5 & 3 & 0.62 & 2.38 & 1.00 & 0.01 & 0.02 \\
Asparagaceae & 6 & 3 & 0.75 & 2.25 & 1.00 & 0.03 & 0.03 \\
Typhaceae & 3 & 2 & 0.37 & 1.63 & 1.00 & 0.04 & 0.04
\end{tabular}

$S$, species flora; $M$, medicinal species; $E$, expected medicinal species; $M-E$, residual $P \leq M$, probability for $M$ or fever; $P=M$, probability of $M ; P \geq M$, probability of $M$ or more.

(Urtica and Parietaria). The same might be true for the high ranked Polygonaceae in Sardinia, which include 6 species of the Rumex genus. The low ranked Fabaceae and Poaceae are classical food taxa comprising the founder crops.

The plant families contributing most species to the medicinal flora of both islands are: Asteraceae ( $\mathrm{Si} 49 / \mathrm{Sa} 38$ ), Lamiaceae ( $\mathrm{Si}$ 22/Sa 26), Fabaceae (Si 20/Sa 16), Rosaceae (Si 18/Sa 16), Apiaceae (Si 17/Sa 14), Brassicaceae (Si 13/Sa 13). After Berendes (1902) the plant families contributing most species to De Materia Medica are: Asteraceae (60), Apiaceae (51), Lamiaceae (51), Fabaceae (35), Rosaceae (29) and Brassicaceae (24). Hence, the first 6 plant families contributing most species to the medicinal flora are the same all over with nearly the same order of importance. The exception are the 51 Apiaceae species mentioned in Berendes' De Materia Medica.

\subsection{Cross cultural analysis and $\chi^{2}$-test}

We can observe a highly significant concentration of medicinal species in the part of the flora shared by both islands. In total the flora common to both islands (1573) accumulate 417 medicinal species while the non-Sicilian flora (540) counts with 29 medicinal species and the non-Sardinian flora (838) with 27 medicinal species (Graphic 1). Reasons for such a distribution might be manifold. The flora common to both islands might generally experience a wider distribution because these species are more ecologically adaptive and they might contain more weedy and annual species with a higher tendency to produce phytochemicals-hence, potentially more pharmacologically active plants, i.e. medicinal plants (c.f. Stepp and Moerman, 2001).

Species with a wider distribution (around the Mediterranean basin) would have also had a higher chance of being selected and recognized as a medicinal species by a specific culture. On the other hand, if once a plant is selected as a medicinal (or food) plant, the probability that its usage or/and its germplasm is being spread in an anthropogenic way (around the Mediterranean basin and elsewhere) rises.

Table 6

Plant families underrepresented among the Sicilian medicinal flora.

\begin{tabular}{lrrrrrrr}
\hline Family & \multicolumn{1}{c}{$S$} & \multicolumn{1}{c}{$E$} & \multicolumn{1}{c}{$M$} & $M-E$ & $P \leq M$ & $P=M$ & $P \geq M$ \\
\hline Plumbaginaceae & 46 & 1 & 5.72 & -4.72 & 0.02 & 0.01 & 1.00 \\
Cyperaceae & 59 & 1 & 7.34 & -6.34 & 0.00 & 0.00 & 1.00 \\
Orchidaceae & 67 & 0 & 8.34 & -8.34 & 0.00 & 0.00 & 1.00 \\
Caryophyllaceae & 107 & 3 & 13.31 & -10.31 & 0.00 & 0.00 & 1.00 \\
Fabaceae & 240 & 16 & 29.86 & -13.86 & 0.00 & 0.00 & 1.00 \\
Poaceae & 236 & 8 & 29.37 & -21.37 & 0.00 & 0.00 & 1.00
\end{tabular}

$S$, species flora; $M$, medicinal species; $E$, expected medicinal species; $M-E$, residual $P \leq M$, probability for $M$ or fever; $P=M$, probability of $M ; P \geq M$, probability of $M$ or more. 
Table 7

Pearson's $\chi^{2}$-test.

\begin{tabular}{llll}
\hline & Sardinia used & Sardinia not used & Total \\
\hline Sicily used & 170 & 102 & 272 \\
Sicily not used & 145 & $x=0-1156$ & $145-1301$ \\
Total & 315 & $102-1258$ & $417-1573$ \\
\hline
\end{tabular}

Most importantly, 170 species (Tables 9a-c, supplementary data) of the 417 medicinal species present in the flora common to both islands are of medicinal use on both islands. We performed a $\chi^{2}$-test on the basis of the effectively shared and non-shared medicinal species (total 417) and calculated a 95\% confidence interval for the number of shared medicinal plants to be expected if the selection had been done at random in order to create a reference value for better exemplification (Table 7). Therefore, we adopted the non-used species as a variable $\mathrm{x}$ with values between 0 and 1156.

According to the $\chi^{2}$-test getting 170 matches might be a plausible result if the peoples had chosen from a pool of plants containing between 477 and $539(60 \leq x \leq 122)$ (medicinal) species (95\% confidence interval, mean $=504 ; x=87$ ). The fact that they have chosen from a pool of 1573 (potential medicinal) species renders the observed matches highly significant and $\mathrm{Ho}=$ "plants have been chosen at random" is rejected.

Hence, the 170 medicinal species used on both islands clearly reflects a common cultural knowledge or common selection criteria; but where did or does that common knowledge come from? One reason is for sure the inter-cultural selection criteria with the tendency to pick medicinal plants from a few preferred plant families and the almost complete rejection of other plant families as evidenced by the binomial approach. The incorporation of synanthropic weedy species thriving in the crop fields and in human vicinity might be another factor that biases the selection (c.f. Stepp and Moerman, 2001; Leonti et al., 2006).

On the other hand people and peoples exchanged knowledge ever since. What was changing over time was the means of knowledge interchange. Writing profoundly revolutionized the transmission of knowledge and, while De Materia Medica was not the first treatise on drugs and medicinal plants, it surely was the most comprehensive and most widely divulged. De Materia Medica generally includes widespread species (or "kinds" of plants) and commercialized plant products. In fact, in his chapters Dioscorides makes reference to the varying plant names in the different European and Mediterranean regions, which implies a broader distribution of these species or species complexes.

Overall, $47 \%$ of the 299 medicinal species of Sicily are mentioned in Berendes' translation while $16 \%$ are neither mentioned on the genus level. From the 344 medicinal species of Sardinia 50\% are referred to by Berendes while $16 \%$ are not so on the genus level. Hence, about the same percentage of medicinal plants of the Sicilian and the Sardinian inventory are mentioned by Berendes.

Of the 170 species used in Sardinia and Sicily, 106 (62\%) are identified by Berendes (1902) while other 50 species belong to a genus identified by Berendes (like for instance the Verbascum spp.) and 16 species (9\%) are not included, neither on the level of the genus (c.f. Tables 9a-c, supplementary data). The fraction of species mentioned in Berendes (1902) is lower in the non-Sardinian and non-Sicilian flora, while the percentage of species not mentioned is higher (Table 8).

This can have two distinct meanings: Either these 106 species included in Berendes' De Materia Medica and the ethnomedicinal flora of Sicily and Sardinia belong to a core-group of plants which are highly effective (and do have an ancient history) or its just a reflection of De Materia Medica and the difficulties peoples had in
Table 8

\begin{tabular}{lclc}
\hline $\begin{array}{l}\text { Medicinal flora Si } \\
\text { and Sa 473 spp. }\end{array}$ & $\begin{array}{l}\text { Species cited } \\
\text { by Berendes }\end{array}$ & $\begin{array}{l}\text { Genus cited } \\
\text { by Berendes }\end{array}$ & $\begin{array}{l}\text { Not cited by } \\
\text { Berendes }\end{array}$ \\
\hline 299 Sicily tot & $142(47 \%)$ & $110(37 \%)$ & $47(16 \%)$ \\
344 Sardinia tot & $171(50 \%)$ & $117(34 \%)$ & $56(16 \%)$ \\
170 Sic. \& Sar. & $106(62 \%)$ & $48(28 \%)$ & $16(9 \%)$ \\
102 Sic. & $31(30 \%)$ & $48(47 \%)$ & $23(23 \%)$ \\
145 Sar. & $57(39 \%)$ & $53(37 \%)$ & $35(24 \%)$ \\
27 Non-Sar. & $5(19 \%)$ & $14(52 \%)$ & $8(30 \%)$ \\
29 Non-Sic. & $8(28 \%)$ & $16(55 \%)$ & $5(17 \%)$ \\
\hline
\end{tabular}

interpreting Dioscorides' text, i.e.: These are the plants that were available and could be deciphered from the various editions of De Materia Medica with less ambiguity. If an experienced pharmacist like Berendes has pronounced difficulties in identifying plants mentioned by De Materia Medica, generations before him, and all the lay and expert men and women that used De Materia Medica from the day onwards that the work was written, had very probably the same. However, for this analysis the correct identification of the plant species originally assembled by Dioscorides is not paramount and we will never have full certainty about the species and the eventual species complexes Dioscorides had in mind. What is important is the interpretation and translation of Dioscorides' text. The data on traditional medicine gathered in Sicily and Sardinia and used in our comparison seem to sustain the probability of Berendes' suggestions on Dioscorides' plant species and vice versa.

De Materia Medica includes a great variety of drugs and many of these were for most of the time not available for the larger part of the inhabitants of Sicily and Sardinia. Such drugs might have been ignored or substituted by local drugs (c.f. Prieto, 2005).

The ethnomedicinal flora of Sardinia contains more species than the ethnomedicinal flora of Sicily. This is unexpected since Sicily harbours more plant species and because more single works were included into the compilation of the medicinal flora of Sicily. As well, Sicily has received more profound cultural impacts and influences during history than Sardinia. We are aware that the field study sites in Sicily cluster in the north-western part (Trapani) and in the eastern part of the province of Palermo and that this could have an impact on the homogeneity and species diversity (Map 1). However, we hypothesize that the higher homogeneity is due to a more intense diffusion of phytotherapeutical knowledge through written records and oral interchange and due to stronger homogenization of the cultural influences in Sicily as a whole. In fact Sicilian (Siculo) is regarded as a language on its own right expressed through various mutually intelligible dialects while the debate on the Sardinian dialects (or languages) continues.

\section{Conclusions}

We identified a core-group of medicinal species that are medicinal in Sicily as well as in Sardinia. These species unite the major part of the citations and moreover are best represented in Berendes' translation of De Materia Medica. The congruence of many specific uses reported in De Material Medica with those observed in the ethnomedicinal studies of Sardinia and Sicily prompts us to conclude that many uses derive more or less directly from De Materia Medica and that the medicinal plant knowledge in Sicily and Sardinia is a shallow stereotype of the various editions of De Materia Medica. In view of our data and analysis it gets difficult to talk of a traditional Sardinian or Sicilian ethnopharmacopoeia since it cannot be distinguished readily form each other. However, there do exist species like Arbutus unedo and Myrtus comunis in Sardinia and Opuntia ficus-indica, Laurus nobilis and Cynodon dactylon in Sicily, which are characteristic for the traditional herbal medicine 
of either islands. This might as well reflect different patterns of folk pathology and the need for specific cures like the apparent need for diuretics in Sicily.

Early herbals or guides to drugs, especially such comprehensive operas as De Materia Medica made it possible to transmit medicinal plant knowledge with a far higher accuracy and more detail than oral tradition would have been able to. De Materia Medica had few or no competition for most of the time and therefore was able to homogenize knowledge about medicinal plants all over Europe and the Mediterranean. At the end it seems that it is the knowledge and interpretation of a single author book, the content of which was divulged by medical doctors and clergymen and then reflected by folk application, that has become what is now termed traditional medicine in the area under analysis.

De Materia Medica includes the first thoroughly approached ethnobotanical survey of the Mediterranean because it is a collection of relevant medicinal information for single species from various parts of the Roman Empire and beyond. Nonetheless, ethnobotanical studies in Europe and especially in the Mediterranean continue to ignore the ethnomedicinal richness, the quality and accuracy of the descriptions of Dioscorides and the fact that knowledge over the past 2000 years about medicinal plants has increasingly spread by written words in the Mediterranean and beyond. In this respect, it is problematic to talk of oral traditions referring to the knowledge of medicinal plants in (this part of) the Mediterranean.

The species included in the ethnomedicinal knowledge of both islands contain a large number of taxa thriving in degraded environments such as the various succession zones of the "Macchia Mediterranea". These are largely widespread and common species, including many weeds, not facing threat of extinction. The few endemic and local species among the medicinal species of both islands does not justify using traditional medicinal practices as an argument for conservation biology or vice versa, at least not in the area under analysis. Such approaches appear not scientifically sound and chumming up. This coincides with conclusions made by Stepp and Moerman (2001): "Widely utilized medicinal plants need to be abundant and accessible. Rare plants are not often found in medicinal floras because they either quickly become extirpated or are brought under cultivation, and thus cease being rare".

Generally, very few gynaecological uses are recorded, which might reflect an artefact of the fieldwork approach i.e. uneven sex proportion of the informants or the issue has remained unmentioned because the informants were embarrassed. Compared to the indications described in De Materia Medica the under-representation of gynaecological uses is noteworthy.

We have chosen a central but geographically limited part of the Mediterranean in our analysis but hypothesize that written sources, i.e. different versions and translations of De Material Medica, have influenced as well the rest of the Mediterranean more profoundly than many would believe and liked to be true. It is the use of written sources that accentuated the homogenization of medicinal plant use in Europe more than anything else, and helped to form the common ethnobotanical heritage of the area.

In the Americas the traditional medicinal systems, believes and concepts were partially replaced and the codices burned by the conquerors. The Mestizo cultures built up new medicinal theories, believes and approaches inspired by the Native indigenous, European Christian and African cultures. Therefore, we have few ideas about ancient native American medicinal systems. In South-America and especially in Mesoamerica intra-cultural comparisons of medicinal plant usage and concepts thereof may reveal indigenous traditions and help to discern from Western influences (c.f. Heinrich et al., 1998). In Europe, the concepts of traditional medicine and medicinal plant heritage continue to be written down since 2000 years. Therefore, comparisons of medicinal plant usage within Europe and the Mediterranean makes only sense if the historical sources that influenced the areas under comparison are crosschecked in the first place.

\section{Acknowledgements}

Many thanks go to Dott. Giovanni Pilo (Dipartimento Farmaco Chimico Tecnologico, Università di Cagliari), Dr. Juerg Gertsch (Swiss Federal Institute of Technology (ETH), Zürich), Dr. Dezsoe Szalay (Department of Economics, University of Warwick), Dr. Ramón Morales (Real Jardín Botánico de Madrid, CSIC), Ettore Casu (Cagliari), the anonymous reviewers and best wishes to Django for inspiration

\section{Appendix A. Supplementary data}

Supplementary data associated with this article can be found, in the online version, at doi:10.1016/j.jep.2008.10.027.

\section{References}

Amat di San Filippo, P., 1990. Un "Prontuario" di Farmacologia Dioscoridea in Uso nella Sardegna del XVII Secolo. In: Congresso Nazionale dell'Accademia Italiana di Storia della Farmacia. Università degli Studi di Siena, Facoltà di Farmacia. 750 Anno Accademico, pp. 205-224.

Amico, F.P., Sorge, F.G., 1997. Medicinal plants and phytotherapy in Mussomeli area (Caltanissetta, Sicily, Italy). Fitoterapia 68, 143-159 (Nr. 2, map 1).

Apg II, 2003. An update of the Angiosperm Phylogeny Group classification for the orders and families of flowering plants. Botanical Journal of the Linnean Society $141,399-436$

Arcidiacono, S., Napoli, M., Pavone, P., 1999. Piante selvatiche utilizzate nella medicina e nella veterinaria popolare nel territorio di Bronte (Catania). Quaderni di Botanica Ambientale e Applicata 10, 105-118 (Nr. 17, map 1).

Atzei, A.D., 2003. Le piante nella tradizione popolare della Sardegna. Carlo Delfino editore, Sassari.

Atzei, A.D., Orioni, S., Sotigiu, R., 1991. Contributo alla conoscenza degli usi etnobotanici nella Gallura (Sardegna). Bolletino della Società Sarda di Scienze Naturali 28, 137-177 (Nr. 15, map 2).

Atzei, A.D., Orrù, L., Putzolu, F., Rozzo, G., Usala, T., 1994. Le Piante nelle terapie tradizionali della Sardegna Sud-Occidentale. Edizioni della Torre 2004, seconda edizione, riveduta e corretta. (Nr. 14, map 2).

Ballero, M., Fresu, I., 1991. Piante officinali impiegate in fitoterapia nel territorio de Marganai (Sardegna Sud Occidentale). Fitoterapia 62, 524-531 (Nr. 4, map 2).

Ballero, M., Fresu, I., 1993. Le piante di uso officinale nella Barbagia di Seui (Sardegna Centrale). Fitoterapia 64, 141-150 (Nr. 6, map 2).

Ballero, M., Poli, F., 1998. Plants used in folk medicine of Monteleone (Northern Sardinia). Fitoterapia 69, 52-64 (Nr. 5, map 2).

Ballero, M., Bruni, A., Sacchetti, G., Poli, F., 1994. Indagine etnofarmacobotanica de territorio di Arzana (Sardegna orientale). Annali di Botanica LII, 489-500 (Nr. 11, map 2).

Ballero, M., Bruni, A., Sacchetti, G., Poli, F., 1997a. Le piante utilizzate nella medicina popolare nel comune di Tempio Pausania (Sardegna settentrionale). Acta Phytoterapeutica 3, 23-29 (Nr. 9, map 2).

Ballero, M., Floris, R., Poli, F., 1997b. Le piante utilizzate nella medicina popolare nel territorio di Laconi (Sardegna centrale). Bolletino della Società Sarda Scientifica Naturalistica 31, 207-229 (Nr. 10, map 2).

Ballero, M., Sacchetti, G., Poli, F., 1997c. Plants in Folk medicine in the territory of Perdasdefogu (Central Sardinia). Allionia 35, 157-164 (Nr. 12, map 2).

Ballero, M., Floris, R., Sacchetti, G., Poli, F., 1998. Ricerche etnobotaniche nel comune di Ussassai (Sardegna centro-orientale). Atti della Società Toscana di Scienze Naturali Serie B 105, 83-87 (Nr. 13, map 2).

Ballero, M., Poli, F., Sacchetti, G., Loi, M.C., 2001. Ethnobotanical research in the territory of Fluminimaggiore (south-western Sardinia). Fitoterapia 72, 788-801 (Nr. 7, map 2).

Bakels, C., 1982. Der Mohn, die Linienbandkeramik und das westliche Mittelmeergebiet. Archaeologisches Korrespondezblatt 12, 11-13.

Bakels, C., 1984. Carbonised Seeds from Northern France. Analecta Praehistorica Leidensia 17, 1-27.

Barbagallo, C., Grillo, M., Meli, R., 1979. Nota sulle Piante Officinali Spontanee e Coltivate del Territorio di Cesarò. Fitoterapia L, 56-66 (Nr. 3, map 1).

Barfield, L., Koller, E., Lippert, A., 1992. Der Zeuge aus dem Gletscher-Das Raetse der fruehen Alpen-Europaeer. Wien.

Bennett, B.C. Husby, C.E, 2008, Patterns of medicinal plant use: an examination of the Ecuadorian Shuar medicinal flora using contingency table and binomial analysis. Journal of Ethnopharmacology 116, 422-430.

Berendes, J., 1902. Des Pedanios Dioskurides aus Anazarbos Arzneimittellehre in ünf Büchern. F. Enke, Stuttgart. 
Bruni, A., Ballero, M., Poli, F., 1997. Quantitative ethnopharmacological study of the Campidano Valley and Urzulei district, Sardinia, Italy. Journal of Ethnopharmacology 57, 97-124 (Nr. 1A and B, map 2).

Catanzaro, F., 1970. Le piante officinali del territorio di Bivona ( $\mathrm{Ag})$ nella tradizione popolare. Fitoterapia 41, 66-84 (Nr. 15, map 1).

Conti, F., Abbate, G., Alessandrini, A., Blasi, C., et al. 2005. An annotated checklist of the Italian Vascular Flora. Ministero dell'Ambiente e della Tutela del Territorio - Direzione per la Protezione della Natura, Dipartimento di Biologia Vegetale Università degli Studi di Roma "La Sapienza". Palombi e Partner S.r.l. Roma.

Conti, F., Alessandrini, A., Bacchetta, G., Banfi, E., Barberis, G., Bartolucci, F., Bernardo, L., Bonacquisti, S., Bouvet, D., Bovio, M., Brusa, G., Del Guacchio, E., Foggi, B., Frattini, S., Galasso, G., Gallo, L., Gangale, C., Gottschlich, G., Grunanger, P., Gubellini, L., Iiriti, G., Lucarini, D., Marchetti, D., Moraldo, B., Peruzzi, L., Poldini, L., Prosser, F., Raffaelli, M., Santangelo, A., Scassellati, E., Scortegagna, S., Selvi, F., Soldano, A., Tinti, D., Ubaldi, D., Uzunov, D., Vidali, M., 2006. Integrazioni alla checklist della flora vascolare Italiana. Updating of the Italian vascular flora. Natura Vicentina $10,5-74$.

Cosmacini, G., 1997. L'arte Lunga. Storia della Medicina dall'Antichità a Oggi. Editori Laterza, Roma, Bari.

Cossu, N., 1996. Medicina popolare in Sardegna. Dinamiche, operatori, pratiche empiriche e terapie magiche. Carlo Delfino editore, Sassari.

Eberle, G., 1975. Pflanzen am Mittelmeer. Mediterrane Pflanzengemeinschaften Italiens und Griechenlands mit Ausblick auf das ganze Mittelmeergebiet. Verlag von Waldemar Kramer, Frankfurt am Main.

Galt, A.H., Galt, J.W., 1978. Peasant Use of Some Wild Plants on the Island of Pantelleria, Sicily. Economic Botany 32, 20-26 (Nr. 5, map 1).

Giardina, G., Raimondo, F.M., Spadaro, V., 2007. A Catalogue of Plants growing in Sicily. Bocconea 20, 5-582.

Heinrich, M., Ankli, A., Frei, B., Weimann, C., Sticher, O., 1998. Medicinal Plants in Mexico: Healers' Consensus and Cultural Importance. Social Science and Medicine 47, 1859-1871.

Heywood, V.H., 1999. The Mediterranean Region a major Centre of Plant Diversity. In: Heywood V.H., Skoula M. (Eds.), Wild food and non-food plants: Information networking. Chania: CIHEAM-IAMC: 5-15. Cahiers Options Méditerranéennes, v. 38 .

Ilardi, V., Raimondo, F.M., 1992. L'uso tradizionale delle piante nella comunità rurale di Mezzojuso (Palermo). Quaderni di Botanica Ambientale e Applicata 3, 41-51 (Nr. 19, map 1)

Istituto Superiore di Sanità 2001; http://www.iss.it/binary/publ/publi/0129. 1109839452.pdf

Johns, T., 1990. With Bitter Herbs They Shall Eat It: Chemical Ecology and The Origins of Human Diet and Medicine. The University of Arizona Press, Tucson, AZ.

Knoerzer, K.H., 1971. Praehistorische Mohnsamen im Rheinland. Bonner Jahrbuecher $171,34-39$

Knoerzer, K.H., 1992. Pflanzenfunde aus dem bandkeramischen Brunnen von Kueckhoven bei Erkelenz. Vorbericht. In: Res Archaeobotanicae. Berichte des neunten Symposiums Kiel, 1992.

La Biblioteca di Repubblica, 2005. L'Italia 4, Sicilia. Touring Editore s.r.l. Milano.

Laguna, A., 1991 (1555). Pedacio Dioscorides Anazarbeo, Acerca de la materia medicinal y de los venenos mortíferos. La materia medicinal y de los venenos mortíferos. Translated from the Greek and illustarated by Dr. Andrés de Laguna. Facsimile edition of the Consejería de Agricultura y Cooperación de la Comunidad de Madrid, Madrid.

Lardos, A., 2006. The botanical materia medica of the Iatrosophikon-a collection of prescriptions from a monastery in Cyprus. Journal of Ethnopharmacology 104, 387-406.

Lentini, F., 1987. Indagini etnobotaniche in Sicilia; II. L'uso tradizionale delle piante in alcune comunità del Trapanese. Studi Urbinati 60, 151-167 (Nr. 9A-K, map 1).

Lentini, F., 1996. Gli usi tradizionali delle piante di Sant'Angelo Muxaro. In: Atti del Convegno “Natura, Mito \& Storia del Regno Sicano di Kokalos" S. Angelo Muxaro (AG), pp. 33-39 (Nr. 16, map 1).

Lentini, F., Aleo, M., 1991. Indagini etnobotaniche in Sicilia; V. L'uso tradizionale delle piante nel territorio di Erice (Trapani). Atti delle Accademie di Scienze, Lettere e Arti di Palermo. Parte 1: Scienze XI, 67-98 (Nr. 4, map 1)

Lentini, F., Mazzola, P., 1998. Le piante utilizzate nella tradizione locale. In: Raimondo, F.M., Schicchi, R. Il Popolamento Vegetale della Riserva Naturale Dello Zingaro (Sicilia). Università degli Studi di Palermo, Dipartimento di Scienze Botaniche (Nr. 13, map 1).

Lentini, F., Raimondo, F.M., 1990. Indagini etnobotaniche in Sicilia IV. L'uso tradizionale delle piante nel territorio di Mistretta (Messina). Quaderni di Botanica Ambientale e Applicata 1, 103-117 (Nr. 1, map 1).

Lentini, F., Catanzaro, F., Aleo M., 1987-1988. Indagini Etnobotaniche in Sicilia III: L'uso tradizionale delle piante nel territorio di Mazara del Vallo (Trapani). Atti Acc. Sc. Lett. Arti Palermo, pp. 121-146 (Nr. 10, map 1).

Lentini, F., Di Martino, A., Amenta, R., 1994. Contributo alla conoscenza della flora popolare dell'isola di Ustica. Quaderni di Botanica Ambientale e Applicata 5, 47-54 (Nr. 14, map 1).

Lentini, F., Giani, S., Amenta, R., 1995. L'uso popolare delle piante nelle isole Eolie (Sicilia). Acta Technologiae et Legis Medicamenti VI, 351-355 (Nr. 7, map 1).

Lentini, F., Di Martino, A., Amenta, R., 1996a. Le piante di uso popolare nell'Arcipelago delle Pelagie (Agrigento). Atti Convegno "Genziana e specie amaro-aromatiche. Camerino, 117-122 (Nr. 8, map 1).

Lentini, F., Di Martino, A., Amenta, R., 1996b. La flora popolare dell'Isola di Pantelleria (TP). In VIII Convegno S.I.F. “Alla scoperta della Digitale del Gennargentu” Arzana (Nuoro), 70 (Nr. 11, map 1).
Lentini, F., Aleo, M., Amenta, R., 1997. L'uso popolare delle piante nelle Isole Egadi (Sicilia). Acta Phytoterapeutica 4, 88-94 (Nr. 12, map 1).

Leonti, M., Vibrans, H., Sticher, O., Heinrich, M., 2001. Ethnopharmacology of the Popoluca, México: An Evaluation. Journal of Pharmacy and Pharmacology 53, 1653-1669.

Leonti, M., Sticher, O., Heinrich, M., 2003a. Antiquity of medicinal plant usage in two Macro-Mayan ethnic groups (México). Journal of Ethnopharmacology 88, 119-124.

Leonti, M., Ramirez-R, F., Sticher, O., Heinrich, M., 2003b. Medicinal flora of the Popoluca, México: a botanico-systematical perspective. Economic Botany 57, 218-230.

Leonti, M., Nebel, S., Rivera, D., Heinrich, M., 2006. Wild gathered food plants in the European Mediterranean: a comparative analysis. Economic Botany 60, 130-142.

Lev, E., 2002. Reconstructed materia medica of the Medieval and Ottoman al-Sham. Journal of Ethnopharmacology 80, 167-179.

Lev, E., Amar, Z., 2006. Reconstruction of the inventory of materia medica used by members of the Jewish community of medieval Cairo according to prescriptions found in the Taylor-Schechter Genizah collection, Cambridge. Journal of Ethnopharmacology 108, 428-444.

Lev, E., Dolev, E., 2002. Use of natural substances in the treatment of renal stones and other urinary disorders in the medieval levant. American Journal of Nephrology $22,172-179$.

Lilliu, G., 1967. La Civiltà dei sardi. Dal Neolithico all'Età dei Nuraghi. ERI - Edizioni Rai Radiotelevisione Italiana, Torino, Seconda edizione 1975.

Logan, M.H., Dixon, A.R., 1994. Agriculture and the acquisition of medicinal plant knowledge. In: Etkin, Nina L. (Ed.), Eating on the Wild Side. University of Arizona Press, Tucson, pp. 25-45.

Loi, M.C., Poli, F., Sacchetti, G., Selenu, M.B., Ballero, M., 2004. Ethnopharmacology of Ogliastra (Villagrande Strisaili, Sardinia, Italy). Fitoterapia 75, 277-295 (Nr. 8, map 2).

Loi, M.C., Maxia, L., Maxia, A., 2005. Ethnobotanical Comparison between the Villages of Escolca and Lotzorai (Sardinia, Italy). Journal of Herbs, Spices and Medicinal Plants (Nr. 3A and 3B, map 2).

Lopez-Muñioz, F., Alamo, C., Garcia-Garcia, P., 2006. "The herbs that have the property of healing. ..," The phytotherapy in Don Qioxote. Journal of Ethnopharmacology 106, 429-441.

Lo Piparo, F., 1990. La Sicilia Linguistica Oggi. Palermo: Centro di Studi Filologici e Linguistici Siciliani.

Lussu, E., 1951. L'avvenire della Sardegna, in "Il Ponte", anno VIII, no. 9-10, settembre ottobre.

Matthioli, A., MDLXVIII, 1967 (1568). I Discorsi di M. Pietro Andrea Matthioli. Sanese, Medico Cesareo, et del Serenissimo Principe Ferdinando Archiduca d'Austria \& c. Nelli Sei Libri Di Pedacio Dioscoride Anazarbeo della Materia Medicale. Vincenzo Valgrisi, Venezia. Anastatic reproduction in 6 volumes, Roma.

Moerman, D.E., 1991. The medicinal flora of native North America. Journal of Ethnopharmacology 31, 1-42.

Moerman, D.E., 1996. An analysis of the food plants and drug plants of native North America. Journal of Ethnopharmacology 52, 1-22.

Moerman, D.E., Pemberton, R.W., Kiefer, D., Berlin, B., 1999. A comparative analysis of five medicinal floras. Journal of Ethnobiology 19, 49-67.

Napoli, M., Giglio, T., 2002. Usi popolari di piante spontanee nel territorio di Monterosso Almo (Ragusa). Bollettino dell'Accademia Gioenia di Scienze Naturali in Catania 35, pp. 361, 361-402 (Nr. 18, map 1).

Osbaldeston, T.A., 2000. Dioscorides De Materia Medica-Five Books in One Volume: New Modern English Translation. Ibidis Press, Johannesburg, South Africa.

Palmese, T.M., Uncini Manganelli, R.E., Tomei, P.E., 2001. An ethnopharmacobotanical survey in the Sarrabus district (south-east Sardinia). Fitoterapia 72, 619-643 ( $\mathrm{Nr} 2$, map 2).

Pardo-de-Santayana, M., Tardío, J., Heinrich, M., Touwaide, A., Morales, R., 2006. Plants in the works of cervantes. Economic Botany 60, 159-181.

Pitrè, G., 1896. Medicina Popolare Siciliana. In: Barbèra, G. (Ed.), Biblioteca delle Tradizioni Popolari Siciliane, seconda edizione. Firenze, 1949.

Prieto, J.M., 2005. Literatura y Etnofarmacología, El Bálsamo de Fierabás. Boletín Latinoamericano y del Caribe de Plantas Medicinales y Aromáticas 4, 48-51.

Raimondo, F.M., Lentini, F., 1990. Indagini etnobotaniche in Sicilia; I. Le piante della flora locale nella tradizione popolare delle Madonie (Palermo). Naturalista Siciliano 14, 77-99 (Nr.6A-K, map 1).

Riddle, J.M., 1985. Dioscorides on Pharmacy and Medicine. University of Texas press, Austin.

Stepp, J.R., Moerman, D.E., 2001. The importance of weeds in ethnopharmacology. Journal of Ethnopharmacology 75, 19-23.

Valenti, C., Tore G., 1988. Sanità e Società - Sicilia e Sardegna Secoli XVI-XX, Udine, ed. Casamassima.

Wagner, M.L., 1950. La Lingua Sarda. Storia, Spirito e Forma. Riedizione dell'Opera. Bern, Francke, s. d. 1950. Ilisso Edizioni, Nuoro, 1997.

Wasylikowa, K., 1989. Paleoecological characteristics of the settlement periods of the Linear Pottery and Lengyel cultures at Cracow-Nowa Huta (on the basis of plant material). Prezglad Archeologiczny 36, 57-87.

Willerding, U., 1980. Beitraege zur Archaeologie Nordwestdeutschlands und Mitterleuropas. Materialhefte zur Ur- und Fruehgeschichte Niedersachsens 16, 421-456.

Willerding, U., 1988. Lebens- und Umweltverhaelnisse der bandkeramischen Siedler von Roessing. In: Fansa, M. Vor 7000 Jahren. Die ersten Ackerbauern im Leintal. Hildesheim. 